\title{
Culminativity, stress and tone accent in Central Swedish
}

\begin{abstract}
Swedish stress and tone accent exhibits an interesting mixture of properties. I argue that the stress system is arranged in a largely morphological fashion, with clear similarities to dominance systems of Japanese, Basque and Greek, where there is a distinction between accented and unaccented stems, and where prefixes and, in particular, suffixes influence stress/accent placement. A major difference is that none of the lexical specifications for stress in Swedish is pre- or post-accenting, but rather post- and pretonic. Thus, no stress is assigned by affixes, but affixes impose adjacency conditions on stress placement in stems, or else the structure is either inhibited, or becomes noticeably marked. Beside the morphological specifications of stress information, there is a phonological default stress assignment, similar to what we find in Greek. The phonological default of Swedish applies blindly when prosodic specification is lacking at the right edge of prosodic words. An accentual default occurs also in Basque, but it applies at a phrasal level rather than at the word level.
\end{abstract}

Beside stress, Swedish also exhibits a lexical tone ('accent 2', 'grave'), which occurs only in primary stressed syllables, and which (in the analysis assumed here) is mostly assigned from posttonic suffixes to an immediately preceding primary stress. So-called 'accent 1' (acute) is lexically unmarked, but both tonal contours signal prominence in a similar fashion, that is, in a way that is independent of the lexical distinction as such.

Stress and tonal accent both instantiate culminativity. Building on the theory of projecting words and phrases (Itô and Mester 2007), I argue that stress instantiates culminativity within the minimal prosodic word, and tonal accent instantiates culminativity in the maximal prosodic word.

\section{Introduction}

In his discussion of the prototypes for lexical prosodic systems, Hyman (2006, 2009) demonstrates that the common understanding of the notion of 'culminativity' requires the separate statement of two criteria. First, there is obligatoriness which states that every lexical word has at least one syllable which is marked for the highest degree of metrical prominence. The typical property to fill this function is primary stress, as in the Germanic languages and e.g. Greek. Obligatoriness is neutral as to whether there is one or several markers for the highest degree of metrical prominence. The second criterion is culminativity, which states that every lexical word has at most one syllable which is marked for the highest degree of metrical prominence. This notion narrows the possibilities down to one or zero stresses per lexical word.

These criteria are then used in a discussion of so-called 'pitch accent' systems of the Japanese and Northern Bizkaian Basque type, that is systems where there is no stress, but where prominence is signalled by virtue of a tonal prominence. Typically, such systems 
do exhibit culminativity at the word level. However, culminativity is not obligatory at that level (Elordieta 1997, 2003, 2007). In the interest of the comparison with Central Swedish, which is the main focus of this article, I will assume that it is relevant to ask at what level (word, phrase) culminativity and obligatoriness apply. This relativization is a slight departure from Hyman's (2006) conception, but in line with the fundamental assumptions of metrical theory.

\section{Culminativity in Swedish}

The variety of Central Swedish (roughly the standard language) exhibits both stress and tone accent in a particular mixture that sets it apart from most other Germanic languages. The main argument here is that both stress and tonal accents are involved in expressing culminativity in Swedish, at different levels of the prosodic structure. Stress expresses culminativity within the prosodic word, much as in the other Germanic languages, but the stress system as such will here be described in rather different terms from what is commonly the case.

Intonational prominence is instantiated as tonal configurations, often called 'pitch accents', which are superimposed, typically on stressed syllables. While prominence lending pitch accents occur in all Germanic languages, Swedish and Norwegian add a lexical distinction to the prominence function of these tonal configurations. The melodic output of this distinction is often referred to as 'accent 1' and 'accent 2', or 'acute' and 'grave' (or, in the Norwegian tradition, 'toneme 1' and 'toneme 2'). The lexical distinction allows us to see clearly two levels of prominence in the tonal structure, referred to as 'word accent' and 'sentence accent' by Bruce (1977), as 'accent' and 'focus accent' in later work by Bruce (e.g. 1998), and as 'prominence level 1' and prominence level 2' by Myrberg (2010). The two levels might well have corresponding levels in some of the other Germanic languages, but this is not obvious at the present state of the art. The categorical nature of the two prominence levels, and the methodological advantage of having access to a lexical distinction (between the tonal accents 1 and 2) at each level, makes Swedish a good case for a discussion of culminativity and levels. ${ }^{1}$ Central Swedish also exhibits a compound rule, instantiated as a particular association pattern of the tonal configuration of accent 2 , which provides further insight into the tonal structure. The tonal accents, then, exhibit prominence lending properties, beside instantiating a lexical distinction in the tonal domain.

These facts about Swedish, further described below, raise the question of the domains at which obligatoriness and culminativity hold, an issue that does not come up for discussion in Hyman (2009), where the lexical word is the point of departure. Itô and Mester $(2006,2007)$ have recently shown that the prosodic word, presumably a universal category

\footnotetext{
${ }^{1}$ The levels and distinctions are charted in (38) below.
} 
that typically aligns with the lexical word, involves two levels, which they call the 'minimal' and 'maximal prosodic word', respectively. In Swedish, these levels exhibit different correlates, as given in (1).

(1) Domains, obligatoriness and culminativity

a. minimal prosodic word $\left(\omega^{\mathrm{min}}\right)$ : stress is obligatory and culminative

b. maximal prosodic word $\left(\omega^{\max }\right)$ : stress is obligatory, tone accent is culminative

The assumption is that these levels are connected by potentially infinite recursion (Itô and Mester 2006). The description in (1) entails a number of things. First, it predicts that there will be just as many stresses as there are minimal prosodic words in a structure. It follows from (1)a that simplex forms will have only one stress, unlike e.g. German or English (compare Am. English sécretàry with Swedish sekretérare). Thus, there are no phonological secondary stresses in simplex words. ${ }^{2}$ Whenever one finds more than one stress in a word, that word will in fact be a prosodic compound, constituted by two or more minimal prosodic words. There are three morphological sources for prosodic compounds: Real compounds (e.g. $\left((\text { smäll })_{\omega}(\text { kállt })_{\omega}\right)_{\omega}$ 'very cold', $\left((\text { köp })_{\omega}(\text { céntrum })_{\omega}\right)_{\omega}$ 'shopping mall'), derivations with a suffix that constitutes its own prosodic word (e.g. $\left((\text { sjúk })_{\omega}(\text { dóm })_{\omega}\right)_{\omega}$ 'illness', $\left((\text { mójlig })_{\omega}(\text { hét })_{\omega}\right)_{\omega}$ 'possibility', and the so-called formal compounds, that is forms that are morphologically simplex but prosodically compounds: ((även $\left.\left.)_{\omega}(t y ́ r)\right)_{\omega}\right)_{\omega}$ 'adventure', $\left((a ́ l b a)_{\omega}(\text { tróss })_{\omega}\right)_{\omega}$ 'albatross'.

Second, (1)b rather redundantly states that a maximal prosodic word will necessarily contain stress, but it also prevents an odd rule like would-be 'compound destressing'. More importantly, a maximal prosodic word will contain at most one tone accent. It is a well-known fact that the Swedish tone accents are properties of the word rather than the syllable (Bruce 1977), but to be precise regarding what this means, we need to qualify the relevant domain as the 'maximal prosodic word'. In simplex forms, the minimal and the maximal prosodic word are one and the same, and one tone accent is

\footnotetext{
${ }^{2}$ This is a point that could be contested, of course, but the generalization is wide enough to tolerate discussion of cases on the margin. The sorts of cases where secondary stress has been suggested, include the initial syllable of lekotek [le'ku'te:k] 'play place', sliperi [slipę'ri:] (discussed below), and the last syllable of implicit ['Im:plisi't] 'id.', passiv ['pasi'v] 'passive'. In both cases one can argue that the would-be secondary stress is a trace of the derivational history, alternatively due to paradigmatic relations between outputs (for discussion, cf. Riad 2009b).

${ }^{3}$ I will henceforth mark all stresses in Swedish with an acute accent mark, to simply denote 'stress'. It is always the first stress in a complex word that is perceived as the main stress, likely a function of the superimposed tonal accent, which necessarily singles out the first stress, and only sometimes marks one other stress. For the other languages discussed, I shall at times use the same accent symbol to mark culminative accent.
} 
(normally) assigned. In compounds (real or prosodic), one tone accent is assigned to the entire structure, as a particular configuration of accent 2 (see (44) below).

Third, the tone accent is mentioned only in conjunction with culminativity in (1), allowing for the possibility of unaccented maximal prosodic words. This is also sometimes found in running speech, where e.g. auxiliaries (ha 'have', kan 'can'), verbs in construction with an object or adverbial (spela kúla 'play with marbles', komma hém 'come home'), and some adjectives (liten 'little', gammal 'old') are often unaccented. Tone accent is thus not strictly obligatory. However, most lexical words really do carry an accent also in running speech in Central Swedish (Myrberg 2010). ${ }^{4}$

In what follows we shall first take a cursory look at culminativity and obligatoriness in Japanese, Basque and Greek (section 3). In these languages, accent is to a large extent morphologically specified, and we will note some patterns of dominance relations between root + suffix in cases of accentual conflict. A system partly similar to this will then form the basis for an analysis of stress in Central Swedish (section 4). This amounts to a proposal that stress in Swedish is largely morphologically controlled, too, rather than phonologically assigned, otherwise the most common analysis proposed for Germanic languages. Some implications of the morphological view of the stress system for word formation are considered in section 5. A short discussion of tone accent from the perspective of culminativity is offered in section 6 .

\section{Japanese, Basque and Greek}

The properties of the three languages compared are given in (2). In this overview, I will use the 'tone accent' as a cover term for a culminative type of tone configuration. Note that the domain for culminativity may be larger than the prosodic word.

\footnotetext{
${ }^{4}$ (1)b entails that, in the case a compound structure could be deaccented, it would also be stripped of its culminativity at the maximal prosodic word level, and the stresses of the compound parts would be entirely on a par with each other. While the empirical consequences of this remain to be worked out, it means that we take the notion of primary stress in compounds to be a direct function of the association of a pitch accent to the first phonological stress. This immediately raises important issues relating to the Germanic languages that have secondary stress within simplex words. What is the nature of primary stress in them? Is it durational or tonal? We will not look further into this issue here.
} 
(2) Overview of obligatoriness and culminativity

\begin{tabular}{|c|c|c|c|c|}
\hline & $\begin{array}{l}\text { prominence } \\
\text { type }\end{array}$ & $\begin{array}{l}\text { obligatory } \\
\text { culminativity, } \\
\text { prosodic } \\
\text { word }\end{array}$ & $\begin{array}{l}\text { obligatory } \\
\text { culminativity, } \\
\text { intermediate } \\
\text { prosodic domain }\end{array}$ & $\begin{array}{l}\text { obligatory } \\
\text { culminativity, } \\
\text { the highest } \\
\text { prosodic domain }\end{array}$ \\
\hline Tokyo Japanese & $\begin{array}{l}\text { tonal } \\
\text { (no stress) }\end{array}$ & no & no & no \\
\hline $\begin{array}{l}\text { Northern Bizkaian } \\
\text { Basque }\end{array}$ & $\begin{array}{l}\text { tonal } \\
\qquad \text { (no stress) }\end{array}$ & no & no & yes \\
\hline \multirow[t]{2}{*}{ Swedish } & tonal & no $\left(\omega^{\max }\right)$ & yes & \\
\hline & stress & yes $\left(\omega^{\min }\right)$ & & \\
\hline Greek & $\begin{array}{l}\text { stress } \\
\quad \text { (no tonal) }\end{array}$ & yes & & \\
\hline
\end{tabular}

We see here that the two tone accent-only systems, Tokyo Japanese and Northern Bizkaian Basque, both exhibit non-obligatory culminativity in the prosodic word. The stress-only system of Greek, exhibits obligatory culminativity in the prosodic word. Swedish is the only double system in (2), in that it has both stress and tone accent. The tone accents side with Tokyo Japanese and the Northern Bizkaian Basque system, and the stress sides with Greek. Further patterns are possible, for which see e.g. Hyman (2006, 2009, 2011). ${ }^{6}$

A few simple examples of output forms illustrating the pattern for each language are given below. A tone accent is marked as a tonal configuration 'HL, next to the vowel carrying it, whereas stress is marked with an accent mark on the relevant syllable "." We turn to the lexical forms of Swedish in section 4 below.

(3) Tokyo Japanese (Haraguchi 1977)

$\begin{array}{lll}\text { tone accent } & \mathrm{i}^{\mathrm{HL}} \text { noti } & \text { 'life' } \\ & \mathrm{koko}^{\mathrm{HL}} \text { ro } & \text { 'heart' } \\ & \text { atama }^{\mathrm{HL}} & \text { 'head' } \\ \text { no tone accent } & \text { miyako } & \text { 'capital city' }\end{array}$

(4) Northern Bizkaian Basque (Hualde 1999) tone accent $\quad 1 \mathrm{e}^{\mathrm{HL}}$ kuko 'of the place'

\footnotetext{
${ }^{5}$ The chart focuses on the level at which culminativity becomes obligatory by some instantiation of prominence. Hence, we do not look further afield here once we have a 'yes'.

${ }^{6}$ A double system is also found in Goizueta Basque, cf. (Hualde et al. 2008, Hualde et al. 2010), beside the more familiar cases of Serbian/Croatian/Bosnian (Inkelas and Zec 1988), Baltic (Kariňš 1996, Blevins 1993) and Central Franconian (Gussenhoven 1999, 2004, Peters 2007).
} 


$\begin{array}{ll}\text { lagu }{ }^{\mathrm{HL}} \text { nena } & \text { 'the one of the friends' } \\ \text { no tone accent } & \text { lagunen }\end{array}$ 'of my friend'

(5) Greek (e.g. Revithiadou 2007)

$\begin{array}{lll}\text { stress } & \text { fantár-os } & \text { 'soldier, nom.sg' } \\ & \text { uran-ós } & \text { 'heaven, nom.sg' } \\ \text { no stress } & \text { anӨrop-os } & \text { 'man, nom.sg' (output: ánӨropos) }\end{array}$

(6) Swedish

$\begin{array}{llll}\text { stress, tone accent } & \text { sý }^{\mathrm{LH}} \text { rak } & \text { 'angry' } & \text { (focus, accent 1) } \\ \text { stress, tone accent } & \mathrm{s}^{\mathrm{HL}} \text { ýrak } & & \text { (given, accent 1) } \\ \text { stress, tone accent } & \mathrm{e}^{\mathrm{HLH}} \text { lak } & \text { 'mean' } & \text { (focus, accent 2) } \\ \text { stress, tone accent } & \mathrm{e}^{\mathrm{HL}} \text { lak } & & \text { (given, accent 2) }\end{array}$

In (6), 'focus' and 'given' normally correspond to prominence levels 2 and 1, respectively. The tone that is associated to the vowel is placed next to the vowel. Association patterns are given in (42) and (43), below.

\subsection{Dominance and direction}

In systems that have the requirement of culminativity in Hyman's sense, two types of situations may require repair. If the structure lacks a prominence altogether, some routine must add one. If there are too many prominences, one or more must be removed in order for a single prominence to remain. For the first type of case, many languages have a phonological default insertion of prominence. In Swedish, this insertion of stress looks for the rightmost available syllable (cf. (16), below). In Greek, when two unaccented morphemes come together, the default is to place stress on the antepenultimate syllable, cf. (5). In Northern Bizkaian Basque, unaccented words are permitted, but there is a default prominence insertion at the level of the phrase, on the last syllable before the verb (e.g. gure lagun ederra 'our beautiful friend' $\rightarrow$ gure lagun ederra ${ }^{\mathrm{HL}}$, Hualde and Bilbao 1992). This prominence shows up also in isolation, and is then analyzable under the same generalization, but with an elliptical verb (Jun and Elordieta 1997). Culminative domains in Tokyo Japanese tend to be larger than in Osaka Japanese (Beckman 1986, 35), but neither variety imposes obligatoriness on culminativity, even at the highest level of prosodic structure. We leave these cases without further comment here.

In the second type of situation, the issue concerns which of several accents is retained and which is/are removed. The interactions reveal dominance relations that can be straightforward or quite complex (Alderete 2001). A straightforward system is found in Greek, where in case of conflict, the root accent dominates. Morphemes can be accented, 
unaccented, preaccenting (suffixes only, marked “^suffix’), or postaccenting (roots only, marked 'root's').

(7) Greek

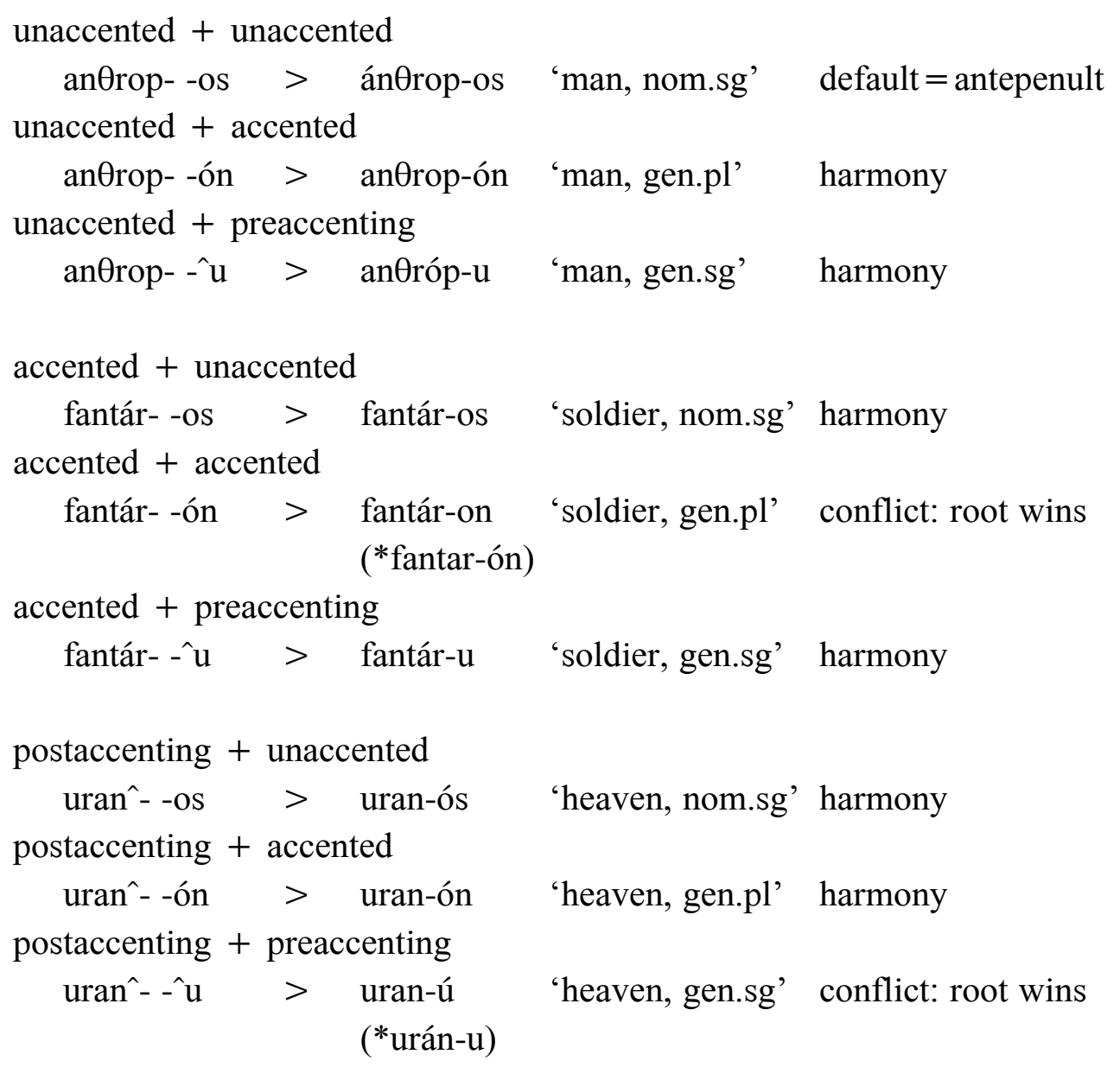

A more complex case is found in Japanese, where there is, on the one hand, an interaction resemblant of Greek (8)a, but with the addition that the dominance property is separated from the presence of an accent, cf. (8)b. The examples are taken from Alderete $(2001,202)$.

(8) Japanese

a. Typical root + suffix interaction

accented root + accented suffix

$$
\text { /yóm + tára/ > [yón-dara] 'if he reads' }
$$

unaccented root + accented suffix

$$
\text { /yob + tára/ }>\text { [yon-dára] 'if he calls' }
$$

b. Dominant suffix

accented root + dominant accented suffix

$$
\text { /adá }+ \text { ppó }_{\text {dom }}+\mathrm{i} / \quad>\text { [ada-ppó-i] 'coquettish' }
$$


unaccented root + dominant accented suffix

$$
\left./ \text { kaze }+ \text { ppó }_{\text {dom }}+\mathrm{i} / \quad>\text { [kaze-ppó-i }\right] \quad \text { 'sniffily' }
$$

accented root + dominant unaccented suffix

$$
/ \text { kóobe }+\mathrm{kko}_{\text {dom }} />\text { [koobe-kko] 'native of Kobe' }
$$

unaccented root + dominant unaccented suffix

$$
\text { ledo }+\mathrm{kko}_{\mathrm{dom}} / \quad>\text { [edo-kko] 'native of Edo' }
$$

This shows that there is not just a power struggle between accents, but between morphemes as such.

The Getxo variety of Northern Bizkaian Basque is a case that shows a pattern like the Greek one, where, in case there is conflicting accent information, the leftmost

\begin{tabular}{|c|c|c|c|}
\hline unaccented & preaccenting & output & gloss \\
\hline lagun & -^ak & lagúnak & 'the friends' \\
\hline gison & -^ak & gisónak & 'the men, abs.' \\
\hline saspi & -^garren-^ak & saspígarrenak & 'the seventh ones, abs.' \\
\hline accented & preaccenting & output & gloss \\
\hline bélarri & -^ak & bélarrik & 'the ears, abs.' \\
\hline báxu & -^en-^ak & báxuenak & 'the shortest ones, abs.' \\
\hline
\end{tabular}
specification wins.

(9) Getxo Basque dominance (Hualde and Bilbao 1992)

Whatever accent specification is leftmost - root or affix - that specification prevails in the output form. Here, then, the dominance relation can be expressed in purely phonological terms.

\section{4. $\quad$ Swedish stress}

The types of dominance interactions that we briefly reviewed above are not generally associated with the Germanic languages and their stress systems. Analyses of English, Dutch, German and Norwegian (Kager 1989, Trommelen and Zonneveld 1999, Hammond 1999, Wiese 1996, Féry 1996, Jessen 1999, Kristoffersen 2000), to mention only a few, are all based on the idea that stress is assigned via a phonological routine (an algorithm) that is essentially sensitive to phonological information, such as word edge and number of syllables. These models typically employ feet (bimoraic or disyllabic) to locate the syllable(s) that should get stressed. Subregular and exceptional stress placement is negotiated by extrametricality, and at times, by lexical specification of vowel quantity, or indeed stress directly. Morphological information, by contrast, is taken to be basically 
invisible, though exceptional behaviour may be connected to certain suffixes. Exceptions are otherwise expressed as lexical specifications with the dedicated property of inhibiting or redirecting the operation of the regular phonological algorithm. Analyses of Swedish stress also generally take a phonological approach, where the default stress placement is usually taken to be on the penultimate syllable. Older phonology-based analyses of Swedish stress have been proposed in work like Öhman (1967), Teleman (1969), and Linell (1972), and more modern proposals include Schmid (1987), Bailey (1990), Andréasson (1997), Shokri (2001), and Frid (2003). The empirical coverage varies quite a lot between these works. The most explicit and complete view of what the stress system would look like in Swedish is probably had by consulting Kristoffersen (2000), which deals with East Norwegian, a language that is stress-wise very similar to Swedish. This work is the most comparable to the other standard works on stress in Germanic languages mentioned above.

Below, I propose a quite different approach to stress in Swedish, one which is much more in line with the lexical nature of the dominance systems seen above. The general spirit of the proposal is that the stress system is largely morphologically determined, where morphemes carry prosodic specifications as part of their lexical representations. These specifications, be it stress or subcategorization for stress, directly determine the stress profile of the output, by themselves or in interaction, in inflection, derivation and compounding. Part of the stress system is phonological, however, in virtue of a simple, exceptionless algorithm that assigns stress when obligatoriness and culminativity are at stake. An important difference vis-à-vis Greek, and (to some extent) Northern Bizkaian Basque, is that the lexical prosodic specifications corresponding to 'preaccenting' and 'postaccenting' are static, that is 'posttonic' and 'pretonic'. 'Posttonic' and 'pretonic' morphemes will not actively assign stress (like the dynamic terms 'preaccenting' and 'postaccenting' indicate), but will simply require for a stress to occur in the relevant position, without being able to, in and of themselves, place a stress there.

The character of the stress system has a number of consequences (extensively discussed below). One effect is that the morphologically determined stresses in Swedish are stable in their syllables, whereas the phonologically assigned stresses vary with the phonological shape and the morpheme sequencing of the word. Another property of the system is that there are no exceptions to the phonological algorithm. This combined morphological and phonological approach removes the need for notions like extrametricality and exceptionally marked quantity or stress in the lexicon, features that are needed in phonology-only accounts. I would argue that, in Swedish at least, these notions are artefacts that go away when the right division of labour is made, between morphological and phonological generalizations. Furthermore, we can use the prosodic properties of morphemes to account for the combinatorics of morphemes in word formation, an area where phonology-based models are silent. This is of particular interest with regard to the 
vexed issue of the notions of 'Germanic' and 'foreign' ('native' or 'non-native', 'French stress rule', etc.) in the lexicon of the Germanic languages (e.g. Baeskow 2004, Linell 1972, Weinstock 1970, Basbøll 2005). It is not an attractive idea to assume such an etymological division of the lexicon and grammar, nor should a language be expected to retain such a division. Instead, we propose, there are differences in the prosodic properties of morphemes, specified in the lexicon. These yield overt and learnable patterns, which appear to, in part, preserve the etymological boundaries between groups of morphemes in the lexicon. As we shall see, conflicts between prosodic specifications do occur in some instances, but the general prediction of the model is that morphemes will combine in a harmonic fashion, that is, they will not freely create words that challenge the realization of lexically specified prosodic properties, and of obligatoriness and culminativity. This allows us to predict that certain combinations of root and suffix will be relatively unmarked and hence more frequent than others. Thus, unlike previous models of stress in Germanic languages, this one has something to say about the general shape of forms in the lexicon. A consequence of this is that word-formation comes out as the main empirical domain in which to study the nature of the stress system.

\subsection{Four prosodic types of morpheme}

The lexical prosodic specifications of Swedish roots and derivational morphemes relating to stress fall into four groups, much as in Greek (cf. (7) above). In Swedish they are prosodically 'unspecified', 'tonic', 'pretonic' and 'posttonic'. ${ }^{7}$ Roots may be either unspecified or tonic, whereas affixes may be of any of the four kinds. No roots are hence ever found in any of the two dependent categories 'pretonic' and 'posttonic'. For the purposes of exposition, I will represent the relevant specifications as foot structure (stress marks and brackets). As mentioned, there is only one stress per minimal prosodic word in Swedish. Beyond that, there is no evidence for foot structure. The foot is thereby relatively inert in Swedish (Riad forthc.). ${ }^{8}$ The stressed syllables, however, are subject to a Stress-toweight condition (a.k.a. Prokosch's law), which requires heavy weight. This is instantiated as a long vowel or a short vowel followed by a long consonant. This structure has all the hallmarks of a bimoraic foot, which is also what we will assume to be the size of the foot in Swedish, with Kristoffersen (2000) and others. Unstressed syllables are all monomoraic. In the interest of clarity, I will avoid the terms 'accented', 'unaccented', etc., in the discussion of the stress system, as there is another level of prosodic structure, superimposed on stress,

\footnotetext{
${ }^{7}$ In addition to these, there are free morphemes like adverb $j u$ (confirming), pronouns den, det 'that' and de 'they', and conjunction/adverb så 'so', etc., which do not form prosodic words, unless contrastively stressed.

${ }^{8}$ For a quite different view of the foot in Swedish, cf. Schmid (1987), Andréasson (1997), Bailey (1990), Frid (2003), and, for Norwegian, Kristoffersen (2000). Shokri (2001) comes a lot closer to the analysis presented here in that he considers final stress as the phonological default.
} 
that is referred to in terms of 'accent' or 'tone accent' (section 6). In (10) below, these terms are however included in brackets to make the correspondence with Greek and the other languages clear. Square brackets mark the syllables that are, or are required to be, feet, by the relevant lexical specifications.

(10) Four types of morpheme

\begin{tabular}{|c|c|c|c|}
\hline \multicolumn{2}{|c|}{ a. unspecified (unaccented) } & \multicolumn{2}{|c|}{ b. tonic (accented) } \\
\hline kalif & 'caliph' & [grís] & 'pig' \\
\hline elektr-icitet & 'electricity' & [vän]-[skáp] & 'friendship' \\
\hline mekan-ik & 'mechanics' & py[já]mas & 'id.' \\
\hline teor-i & 'theory' & chil-[én]-are & 'Chilean' \\
\hline trans-parent & 'id.' & [ó]-[tál]-ig-a & 'innumerable’ \\
\hline \multicolumn{2}{|c|}{ c. posttonic (in the post-accent position) } & \multicolumn{2}{|c|}{ d. pretonic (in the pre-accent position) } \\
\hline [trév]-lig & 'pleasant' & be-[löna & 'reward' \\
\hline [spél]-are & 'player' & för-[’ för-[tála & 'slander' \\
\hline [díkt]-er & 'poems' & & \\
\hline dókt]-or & 'doctor' & & \\
\hline ']-iker mág]-iker & 'magician' & & \\
\hline
\end{tabular}

Just as in Greek and Basque, structures that consist of unspecified (unaccented) morphemes only receive stress by virtue of a phonological constraint or rule, here called RIGHTMOST, which requires stress on the rightmost available syllable.

\section{(11) Rightmost (Align-R(HdFt,PrWd)) ${ }^{9}$}

'The rightmost available syllable in the minimal prosodic word is stressed'

The forms in (10)a thus have outputs like (kalíf) $)_{\omega}$, (elektricitét) $)_{\omega}$, (mekaník) $)_{\omega}$, (teorí) $)_{\omega}$ and (transparént) $)_{\omega}$. The import of 'available' here is that phonological stress placement is sensitive to lexical prosodic information. Thus, if the last syllable of a structure is a posttonic suffix, then the last available syllable will be the syllable preceding that suffix (cf. section 4.5 below). RightMOST will guarantee that the condition of obligatory culminativity is met in minimal prosodic words, the domain for stress. We might now formalize culminativity as the following constraint.

\section{(12) Culminativity-PrWd (obligatory)}

'The prosodic word has exactly one head/stress'

\footnotetext{
${ }^{9}$ This constraint corresponds to e.g. Rice's $(2006,1177)$.
} 
Both of these constraints are high-ranking in the grammar. In the next few sections, the four types of morpheme are briefly presented, together with some arguments supporting the lexical status of the prosodic information. After that, we turn to more general patterns that fall out as natural from the morphological perspective.

\subsection{Prosodically unspecified morphemes}

Morphemes that lack prosodic specification can be roots or affixes and are mostly easy to identify. While such morphemes will vary between stressed and unstressed in the output, they are seen to be stressed only when final in the prosodic word, or when they are directly followed by a posttonic morpheme. Typical morphemes of this sort are what would in other models often be categorized as 'foreign', 'French', 'Romance', 'Latinate' or 'learned'. Some examples are given in (13). The variation in stress placement is due to the prosodic type of suffix, as discussed below. Unspecified roots typically look like cranberry morphemes, or at least "incomplete", without endings on them. Only very few roots of this type are free morphemes, e.g. kalíf'caliph'.

(13) Prosodically unspecified roots

$\begin{array}{llll}\text { ark-ád } & \text { 'arcade' } & \text { gent-íl } & \text { 'generous' } \\ \text { bal-áns } & \text { 'balance' } & \text { kab-ín } & \text { 'cabin' } \\ \text { ban-ál } & \text { 'id.' } & \text { kalíf } & \text { 'caliph' } \\ \text { biblio-ték } & \text { 'library' } & \text { kok-étt } & \text { 'coquettish' } \\ \text { brilj-ánt } & \text { 'brilliant' } & \text { matemat-ík } & \text { 'mathematics' } \\ \text { cýkl]-isk } & \text { 'cyclic' } & \text { nat-ión [nat'furn] } & \text { 'id.' } \\ \text { ackompanj-ér]a } & \text { 'accompany' } & \text { exeg-ét } & \text { 'exegete' } \\ \text { äm-ábel } & \text { 'amiable' } & \text { fig-úr } & \text { 'figure' } \\ \text { dek-ál } & \text { 'sticker' } & \text { solv-ént } & \text { 'id.' } \\ \text { eléktr]-iker } & \text { 'electrician' } & \text { teor-ét]-isk } & \text { 'theoretical' }\end{array}$

Below are some unspecified adjectival, verbal and nominal suffixes.

(14) Prosodically unspecified suffixes

$\begin{array}{cllll}\text { a. adjectival } & \text { dekad-ént } & \text { 'decadent' } & \text { minuti-ôs } & \text { 'meticulous' } \\ & \text { delik-át } & \text { 'delicious; delicate' } & \text { mod-ést } & \text { 'id.' } \\ & \text { grac-íl } & \text { 'slender' } & \text { nation-éll } & \text { 'national' } \\ & \text { grandi-ós } & \text { 'grandiose' } & \text { obsk-ýr } & \text { 'obscure' } \\ & \text { grav-íd } & \text { 'pregnant' } & \text { signifik-ánt } & \text { 'significant' } \\ & \text { grot-ésk } & \text { 'grotesque' } & \text { viol-étt } & \text { 'violet' } \\ \text { kommun-ál } & \text { 'municipal' } & \text { vulg-ár } & \text { 'vulgar' }\end{array}$




\begin{tabular}{|c|c|c|c|c|}
\hline \multirow[t]{5}{*}{ b. verbal } & fabr-ic-ér]-a & 'fabricate' & kvalif-ic-ér]-a & ‘qualify’ \\
\hline & finans-iér]-a & 'finance' & mumi-fi-ér]-a & 'mummify' \\
\hline & glor-ifi-ér]-a & 'glorify' & oper-ér]-a & 'operate' \\
\hline & kondens-ér]-a & 'condense' & proj-ic-ér]-a & 'project' \\
\hline & kopi-ér]-a & ‘copy’ & strat-ifi-ér]-a & 'stratify' \\
\hline \multirow[t]{26}{*}{ c. nominal } & abbed-íss]-a & 'abbess' & kaps-ýl & 'cap' \\
\hline & akv-ár]-ium & 'aquarium' & klaviat-úr & 'keyboard' \\
\hline & ark-ív & 'archive' & kommiss-ión & 'commission' \\
\hline & arab-ésk & 'arabesque' & kompan-í & 'company' \\
\hline & arkiv-ár]-ie & 'archivist' & konven-áns & 'propriety' \\
\hline & arr-ést & 'detention' & kub-ísm & 'cubism' \\
\hline & borgen-är & 'creditor' & kurt-ís & 'flirtation' \\
\hline & dans-ös & 'danser, fem.' & lärar-ínn]-a & 'teacher, fem.' \\
\hline & dek-án & 'dean' & lok-ál & 'premises' \\
\hline & delikat-éss & ‘delicacy' & univers-itét & 'university' \\
\hline & desp-ót & ‘id.' & obduc-ént & 'pathologist' \\
\hline & diagn-ós & 'diagnosis' & patri-árk & 'patriarch' \\
\hline & disko-ték & 'discoteque' & pil-ót [-u:t] & 'id.' \\
\hline & divid-énd & ‘id.' & polit-ýr & 'polish' \\
\hline & doktor-ánd & 'graduate student' & predik-ánt & 'preacher' \\
\hline & dru-íd & ‘id.' & prins-éss]-a & 'princess' \\
\hline & evene-máng & 'event' & proveni-éns & 'provenance' \\
\hline & firma-mént & 'id.' & rept-1́l & 'reptile' \\
\hline & gar-áge & 'id.' & rond-éll & 'roundabout' \\
\hline & gard-ín & 'curtain' & sark-óm & 'sarcoma' \\
\hline & gen-és & 'genesis' & servi-trís & 'waitress' \\
\hline & graf-ík & 'graphic art' & skorpi-ón [-u:n] & 'scorpion' \\
\hline & har-áng & 'harangue' & solips-íst & 'id.' \\
\hline & kabin-étt & 'cabinet' & suffl-ör & 'prompter' \\
\hline & kalif-át & 'caliphate' & troll-erí & 'magic' \\
\hline & kanon-ád & 'cannonade' & & \\
\hline
\end{tabular}

For the verbal suffixes the morphological break-off point is not very clear. There are several variants of what is basically the same verbal ending: -era, -iera, -isera, -fiera, -ifiera, -ificera. They are all formed by the morph -er- followed by regular verbal inflection -a (for infinitive), -ar (for present tense), 
etc. ${ }^{10}$ What precedes -er- may either belong to the ending or the stem, without consequences for the prosodic analysis given here.

For nouns, as for adjectives, there are plenty of suffixes. The definition of 'suffix' here is based on the formal properties of segmentation, rather than on meaning. Thus, the crucial criterion resides in the separability of the suffix from a root or from other suffixes, e.g. by virtue of occurring with other roots. To take an illustrative example, $-y m$ is considered a suffix in view of data like parf-ym, 'perfume', kut-ym 'custom', kost-ym 'suit' and vol-ym 'volume'. This formal definition of 'suffix' (or indeed more generally of 'morpheme') might seem to increase subjectivity, but is more reliable than any definition based on semantic content. First of all, it is very difficult to determine just when a suffix carries independent meaning. Many suffixes contain little meaning beyond the grammatical category they instantiate. Nominalizers like e.g. -het, -skap and -itet fall in this category, and are never contested as suffixes. With Latinate and Greek roots, which strongly tend to require a suffix not to look like cranberry morphemes, the productivity of endings varies greatly, and so does the raw frequencies. The status of -tion as a suffix is probably not in question for anyone, but $-y m$ might well be. But there is no difference in principle between them, only one in frequency. If we require of morphemes to have a clear and delimitable meaning, the ending -tion is going to be considered now a suffix (argumenta-tion 'id.'), now part of a monomorpheme (nation 'id.'), depending on the independence of the rest of the word. As there is no consistent way of defining morphemes on the basis of meaning alone, or together with productivity, it makes more sense to take the formal approach, and consistently identify morphemes where the language indicates a morphological divide.

There are also prefixes that are prosodically unspecified, a few of which are given in (15).

(15) Prosodically unspecified prefixes

$\begin{array}{llll}\text { trans-parént } & \text { 'id.' } & \text { ad-jungér]-a } & \text { 'call in; adjoin' } \\ \text { pre-positión } & \text { 'id.' } & \text { in-divíd } & \text { 'individual' } \\ \text { pro-fanér]-a } & \text { 'to profane' } & \text { des-informér]-a } & \text { 'disinform' }\end{array}$

In forms constituted exclusively by unspecified morphemes, stress shows up on the last morpheme, as per RightMost, cf. (11). When unspecified suffixes are stacked, as they frequently are, stress will seem to move further and further to the right. ${ }^{11}$

\footnotetext{
${ }^{10}$ These are posttonic (cf. below), hence marked with a square bracket in (14).

${ }^{11}$ Each form in (16) constitutes a single prosodic word. This is established by looking at syllbification. As in other Germanic languages, the minimal prosodic word is the domain for syllabification in Swedish (cf. Riad forthc.).
} 
(16) Strings of prosodically unspecified morphemes ${ }^{12}$

\begin{tabular}{|c|c|c|}
\hline (nat-ión) $)_{\omega}$ & (nat-ion-éll) $)_{\omega}$ & (nat-ion-al-íst $)_{\omega}$ \\
\hline$(\text { pro-dúkt })_{\omega}$ & (pro-duk-tión) & (pro-duk-tiv-itét $)_{\omega}$ \\
\hline$(\text { ban-ál) })_{\omega}$ & (ban-al-itét $)_{\omega}$ & (ban-al-is-ér]-a $)_{\omega}$ \\
\hline ans-planta-tión) $)_{\omega}$ & (trans-planta-tion-éll) $)_{\omega}$ & \\
\hline $\operatorname{arakt}-a ̈ r)_{\omega}$ & $(\text { karakt-er-ist-ík })_{\omega}$ & (karakt-er-is-ér]-a \\
\hline
\end{tabular}

The most important indicator of phonological stress, as opposed to morphological (tonic) stress, is the fact that, within the prosodic word, unspecified morphemes either carry primary stress or are entirely unstressed (whenever stress falls elsewhere). Tonic morphemes carry true lexical stress and are not flexible in this way (cf. (19) below). Tonic morphemes tend always to be stressed, but in the few contexts where their stress must be removed, they leave traces of stress behind (vowel quality and quantity). This difference between 'unspecified' and 'tonic' is thus empirically manifest (documented below). To establish the status of morphemes as unspecified we should look at alternations in syllables where stress induces vowel length. In such syllables, the quality as well as the quantity of the vowel varies quite distinctly. The relevant vowels to compare are given in phonetic transcription in (17).

(17) Prosodically unspecified morphemes: no trace of vowel length

phoneme allophones long stressed

\begin{tabular}{|c|c|c|c|}
\hline \multirow[t]{2}{*}{ /i/ } & \multirow[t]{2}{*}{ i: $\sim$ I } & \multirow{2}{*}{$\begin{array}{l}\text { pol['ii]tiker 'politician' } \\
\text { mask['ii]n 'engine' }\end{array}$} & \multirow{2}{*}{$\begin{array}{l}\text { pol[I]tiséra 'politicize' } \\
\text { mask[I]nerí 'machinery' }\end{array}$} \\
\hline & & & \\
\hline$/ \mathrm{y} /$ & $\mathrm{y}: \sim \mathrm{Y}$ & $\mathrm{f}[$ 'y:] siker 'physicist' & f[y]sikálisk 'physical' \\
\hline \multirow[t]{2}{*}{ /e/ } & $\mathrm{e}: \sim \varepsilon$ & prof['e:]t 'prophet' & prof[ع]téra 'prophecy' \\
\hline & & obsc['e:]n 'obscene' & obsc $[\varepsilon]$ nitét 'obscenity' \\
\hline \multirow[t]{2}{*}{ /Ø/ } & $\varnothing: \sim \varnothing$ & milj['ø:] 'environment' & $\begin{array}{l}\text { "milj[ø]dî" 'environmental } \\
\text { melody' }\end{array}$ \\
\hline & $œ: \sim\left(_{-} r\right.$ & kommend['œ:]r 'commodore' & f[œ]rändra 'change' \\
\hline \multirow[t]{2}{*}{$/ \mathrm{a} /$} & $\mathrm{a}: \sim \mathrm{a}$ & $\operatorname{dr}[$ 'a: $] \mathrm{ma}$ 'drama' & dr[a]mátisk 'dramatic', \\
\hline & & & dr[a]matík 'drama' \\
\hline /o/ & O: $\sim 0 / U$ & elektr['o:]n 'electron' & elektr[o]ník 'electronics' \\
\hline \multirow[t]{2}{*}{$/ \mathrm{u} /$} & $\mathrm{u}: \sim \mathrm{U}$ & positi['u:]n 'position' & positi[u]néra 'position, vb.' \\
\hline & & fas['u:]n 'shape' & fas[u]néra 'shape, vb.' \\
\hline \multirow[t]{2}{*}{$/ \mathfrak{t} /$} & $\mathbb{H} \sim \mathbb{Z}$ & komm['z:]n 'municipality' & komm[u]nárd 'Communard' \\
\hline & & kult[' $t:] \mathrm{r}$ 'culture' & kult[u]réll 'cultural' \\
\hline
\end{tabular}

\footnotetext{
${ }^{12}$ Translations are left out here as the meanings are very similar to the English cognates.
} 
These radical changes in vowel quality and quantity between stressed and unstressed position are here assumed to be due to the phonological character of stress. This interpretation relies on the observation that things are different with lexical stresses, i.e. tonic morphemes, to which we now turn.

\subsection{Prosodically specified morphemes: tonic}

Tonic morphemes contain a lexical stress. We shall represent this as lexical foot structure, indicated with square brackets around the stressed syllable, and a stress mark "”. The boundaries of feet will shift around a little depending on syllabification, and I shall assume that the foot boundaries unproblematically align with syllable boundaries. In forms containing more than one stress, there will also be more than one minimal prosodic word.

(18) Tonic morphemes

\begin{tabular}{|c|c|c|c|c|}
\hline \multirow[t]{5}{*}{ a. roots: } & [glöm]-sk & 'forgetful' & scha[brák] & ‘caparison’ \\
\hline & [trév]-lig & 'pleasant' & [ká]viar/kavi[ár] & 'caviar' \\
\hline & [tvắtt]-a & 'wash' & an[sjó]vis & 'anchovies' \\
\hline & [tvä́tt]-are & 'washer' & py[já]mas & 'id.' \\
\hline & [chárm] & 'id.' & & \\
\hline \multirow[t]{6}{*}{ b. suffixes: } & [fränd]-[skáp] & 'friendship' & [úpp]en-[bár] & 'obvious' \\
\hline & [stór]-[hét] & 'largesse' & för[äl]dra-[lós] & 'orphan' \\
\hline & -[V́:n] 'from X' & & -[é:s] 'from X' & \\
\hline & kub-[án] & 'Cuban' & kin-[és] & 'Chinese' \\
\hline & rum-[ä́n] & 'Romanian' & liban-[és] & 'Lebanese' \\
\hline & chil-[én]-are & 'Chilean' & javan-[és] & 'Javanese' \\
\hline \multirow[t]{2}{*}{ c. prefixes: } & [úr]-[trév]-lig & 'very pleasant' & [míss]-[tág] & 'mistake' \\
\hline & [ó]-[märk]-lig & 'imperceptible' & [ín]-[trýck] & 'impression' \\
\hline
\end{tabular}

Tonic morphemes can be roots as well as affixes. They are typically of Germanic origin, but there are also plenty of borrowings in this group, many of which are monosyllabic (like most Germanic roots): chéf 'boss', móusse 'id.', gláss 'ice cream', ský 'gravy', sfär 'sphere', gáge 'fee'. Suffixes, too, may be borrowed, like those indicating origin in (18)b.

In order to establish that a given morpheme is tonic we look at related forms with primary stress in different syllables, and with long vowels in the stressed syllable. Unlike unspecified morphemes, tonic morphemes leave a trace of vowel length and vowel quality behind, if primary stress is moved away. Shifting stress away from a tonic morpheme doesn't come easily, as the unmarked case of derivation is to create a prosodically harmonic structure, where lexical specifications are preserved (cf. section 5). There is, however, a derivational, prosodically unspecified suffix -eri, denoting ongoing 
activity or place where an activity (habitually) takes place, which necessarily creates a single prosodic word with the root it attaches to. This suffix is unusually productive (also in other Germanic languages: German, Dutch -erei, English -ery), such that it can be combined with pretty much any root, tonic or not. ${ }^{13}$ The productivity of this suffix is due to its semantic properties. However, -eri is prosodically unspecified and will therefore create a structure that triggers RightMOST on its final syllable, cf. (11). RightmosT applies blindly whenever its structural description is met. This situation, marked though it is, is what allows us to demonstrate the difference between unspecified roots and tonic roots.

(19) Tonic morpheme + unspecified morpheme (trace of vowel length and quality) ${ }^{14}$

\begin{tabular}{|c|c|c|c|}
\hline phoneme & allophones & long stressed & half-long unstressed \\
\hline \multirow[t]{2}{*}{ /i/ } & $\mathrm{i}: \sim \mathrm{i}$ & sl['ii]pa 'grind; sharpen' & sl[i’]perí 'grindery' \\
\hline & & $\operatorname{gr}[$ 'ii]s 'pig' & $\operatorname{gr}\left[\mathrm{i}^{\prime}\right]$ serí 'messiness' \\
\hline$/ \mathrm{y} /$ & $\mathrm{y}: \sim \mathrm{y}^{\prime}$ & $\operatorname{pr}[$ 'y: $] \mathrm{d}$ 'prudish' & $\operatorname{pr}\left[\mathrm{y}^{\prime}\right]$ deríer 'pruderies' \\
\hline \multirow[t]{3}{*}{ /e/ } & $\mathrm{e}: \sim \mathrm{e}^{\prime}$ & $1[$ 'e: $] \mathrm{k}$ 'game' & 1[e']koték 'play place' \\
\hline & & $\operatorname{ch}[$ 'e:]f 'boss' & $\operatorname{ch}\left[\mathrm{e}^{\prime}\right]$ ferí 'bossing' \\
\hline & & kin['e:]s 'Chinese' & $\operatorname{kin}\left[\mathrm{e}^{\prime}\right]$ serí 'chinoiserie' \\
\hline \multirow[t]{3}{*}{$/ \varnothing /$} & $\varnothing: \sim \varnothing$ & $\mathrm{s}[$ 'Ø:] ka 'seek' & (fel)s[ $\left[\varnothing^{\prime}\right]$ kerí 'trouble shooting' \\
\hline & & $\mathrm{g}[$ 'ø:]ta- 'Geat-' & g[ø’]ticísm 'Geatishness' \\
\hline & $œ: \sim œ^{r} \_r$ & $\mathrm{n}[$ 'œ:] rd 'nerd' & n[œ']rderí 'nerdery' \\
\hline \multirow[t]{2}{*}{$\mid \varepsilon /$} & $\varepsilon: \sim \varepsilon^{\prime}$ & kl['E:]der 'clothes' & $\mathrm{kl}\left[\varepsilon^{\prime}\right]$ derí '(constant) dressing' \\
\hline & $æ: \sim æ^{\prime} \_r$ & b['æ:]ra 'carry' & (brev)b[æ']rerí 'postman activity' \\
\hline \multirow[t]{3}{*}{$/ \mathrm{a} /$} & $\mathrm{a}_{\mathrm{i}} \sim \mathrm{a}^{\prime}$ & b['a:]gare 'baker' & $\mathrm{b}\left[\mathrm{a}^{`}\right]$ gerí 'bakery' \\
\hline & & $\mathrm{d}[$ 'a: $]$ tor 'computer' & $\mathrm{d}\left[\mathrm{a}^{\top}\right]$ torték 'computer place' \\
\hline & & charlat['a:]n 'id.' & charlat[a']nerí 'charlatanism' \\
\hline /o/ & $\mathrm{O}: \sim \mathrm{O}^{\prime}$ & sk['o:]da 'behold' & (navel)sk[o']derí 'navel-gazing' \\
\hline \multirow[t]{4}{*}{$/ \mathrm{u} /$} & $\mathrm{u}: \sim \mathrm{U}^{*} / \mathrm{U}$ & k['u:]ka 'boil' & $\mathrm{k}\left[\mathrm{U}^{\prime}\right] \mathrm{kerí}, \mathrm{k}[\mathrm{U}]$ kerí '(place for) \\
\hline & & & boiling' \\
\hline & & $\operatorname{pr}[$ 'u:]sa 'prose' & pr[U']saíst, pr[U]saíst 'id.' \\
\hline & & $\mathrm{n}[$ 'u:]rden 'the north' & $\begin{array}{l}\mathrm{n}[\mathrm{u}] \text { rdíst 'scholar in Scandinavian } \\
\text { languages' }\end{array}$ \\
\hline \multirow[t]{3}{*}{ / $\mathrm{t} /$} & $\mathrm{H}: \sim \mathrm{H}^{\mathrm{r}} / \mathrm{H}$ & gj['t:]ta 'mould' & 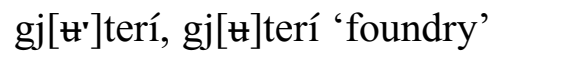 \\
\hline & & $\mathrm{m}[$ 'tz:]ra 'lay bricks' & m[t']rerí 'masonry' \\
\hline & & $1[$ 'tz: $]$ ta 'lute' & $1\left[\mathrm{H}^{\prime}\right]$ teníst 'lute player' \\
\hline
\end{tabular}

\footnotetext{
${ }^{13}$ Another couple of much less productive suffixes (-tek, -ist) have this capacity, too.

${ }^{14}$ Brackets are used here to indicate and highlight the phonetic form of vowels. The so marked vowels all belong to tonic roots, though.
} 
In (19), there are examples of borrowed tonic root morphemes (chef-erí), Germanic tonic root morphemes (slip-erî), and tonic derivational suffixes (kin-es-erí, charlat-an-erî). These examples show that, in contrast with (17), some traces of vowel length remain after main stress has shifted away. Beside quantity, the vowels retain the same quality as they have when stressed. This test of lexical stress works reliably when there is an intervening syllable between the stressed syllables of the base form and the derivation. Full reduction of a lexically stressed syllable may occur when it is adjacent to the new stress, cf. $s t$ ['i:]l 'style', $s t\left[i^{\prime}\right]$ lerí 'activity of styling', but $s t[\mathrm{I}]$ líst 'stylist'.

The traces of stress are interpreted as stress loss rather than as demotion of stress, which has otherwise been the most common interpretation (Linell and Anward 1971, Anward and Linell 1976). Two generalizations are at stake, CULMINATIVITY and the initiality of primary stress in words. Obligatory CULMINATIVITY requires each minimal prosodic word to contain exactly one stress, and the words in (18) and (19) form single prosodic words. In forms containing more than one stressed morpheme (compounds, some derivations), the first stress is invariably perceived as the primary one, an impression that is reinforced by the assignment of postlexical accent 2 by the compound rule (cf. (44) below). If the first, half-long syllable of sliperí were considered as stressed, both of these generalizations would be lost. Forms like sliperí are strongly limited and motivated by the semantic productivity of a certain suffix, which overrides and disregards the presence of a lexical stress. In view of this, we interpret the situation as a conflict between lexical and postlexical information, where faithfulness to the lexical information causes the retention of quality and some quantity of long vowels, even after the stress as such has been removed.

Note that, regardless of how one treats CulminATIVITY, the test as such is valid, the contrast between tonic and unspecified being manifest in near minimal pairs like mask['ii]n mask[I]nerí 'machine machinery' vs. $s I[\mathrm{i}:] p a \sim s I[\mathrm{i}]$ perí 'grind grindery', and mek['a:]nisk mek[a]ník 'mechanical mechanics' vs. ban['a:]n ban[a']nerí 'banana "bananery",

Another test that distinguishes tonic and unspecified morphemes from one another is found in the realization of the suffix -(i)sk, a posttonic morpheme, which alternates between syllabic (']-isk) and non-syllabic form (']-sk). The variation is partly caused by phonotactic and quantitative considerations (Riad 1999), but some variation is directly due to tonicity, as illustrated below.

(20) Epenthesis/no epenthesis in the -(i)sk-suffix

\begin{tabular}{lllc} 
tonic stem-final morpheme & \multicolumn{2}{l}{ unspecified stem-final morpheme } \\
spar[tán]-sk & 'spartan' & mekán]-isk & 'mechanical' \\
*spar[tán]-isk & & *mekán]-sk & \\
[sýn]-sk & 'psychic' & cýn]-isk & 'cynical'
\end{tabular}




$\begin{array}{clll}\text { isra[él]-sk } & \text { 'Israeli' } & \text { israél]-isk } & \text { 'Israeli' } \\ <\text { isra[él] } & \text { 'Israelian' } & <\text { Ísraèl } & \text { 'Israel'15 } \\ \text { [fál]-sk } & \text { 'false' } & \text { aristotél]-isk } & \text { 'Aristotelian' }\end{array}$

There is no epenthesis when the suffix attaches to a tonic morpheme. This could be understood as a faithfulness effect, minimizing epenthesis and thereby the distance between the suffix and the stem. When the stem-final morpheme is prosodically unspecified, however, the prosodic word shape is optimized as disyllabic, counting from the stressed syllable, with epenthesis as a consequence. ${ }^{16}$

\subsection{Prosodically specified morphemes: pretonic}

Swedish has two pretonic morphemes, namely be- and för-. These prefixes are specified to occur in the position before a stressed syllable, and this is strictly true in Swedish (unlike equivalent forms with ge- in Dutch, Kooij 2003).

(21) Pretonic morphemes

$\begin{array}{lll}\text { be-[' } & \text { be-[hóv] } & \text { 'need' } \\ \text { be-[ré]da } & \text { 'prepare' } \\ \text { för-[' } & \text { för-[ákt] } & \text { 'contempt' } \\ & \text { för-[dé]la } & \text { 'distribute' }\end{array}$

The prefixes exhibit a certain productivity. In verbs, för- often means 'make into [root meaning]' as in för-árga 'aggravate', för-sláva 'enslave', för-dýra 'make more expensive', för-svénska 'make Swedish', while be- has a general transitivizing meaning: be-bó 'inhabit', be-kämpa 'fight (against)', be-stíga 'climb', be-tvívla 'doubt'.

The pretonicity of these prefixes is primarily established as a static pattern, as they are only ever found in the position before a stressed syllable. The fact that they are somewhat productive, however, allows us to generate putatively meaningful forms where the pretonicity would not hold, thus admitting a test for native speaker intuition. We may construct semantically sensible, hypothetical forms like ${ }^{+}$för-indignéra 'aggravate' (indignerad 'indignant') and 'be-habitéra 'inhabit', in semantic parallel with för-árga and be-bó. These are intuitively ruled out.

The prosodic word structure of these forms is what Itô and Mester (2006, 2007) would call a projection of the prosodic word, i.e. a structure created by adjoining

\footnotetext{
${ }^{15}$ The name of the country is construed as a formal compound in Swedish.

${ }^{16}$ The argument for the optimal prosodic word in Swedish would take us too far afield here, but suffice it to mention that nicknames invariably are disyllabic, dimorphemic, and stressed on the first syllable: Katarína > Kátt-is, Bó > Bóss-e (for further details cf. Riad 2002, forthc.).
} 
material to the prosodic word, by creating an intermediate projection between the minimal and maximal projections of the prosodic word. The intermediate levels are infinite in number, in principle, because of recursivity. We mark this with an apostrophe, where needed, e.g. (be-(stíga) $\left.)_{\omega}\right)_{\omega}$ 'climb'. The importance of recursion here is that it forms an asymmetric structure, where a prefix combines with a minimal prosodic word. Importantly, there is independent evidence for this structure in the behaviour of syllabification, as well as in the assignment of tone accent (cf. Riad 2009b, forthc.). ${ }^{17}$ The intermediate projections are not to be seen as prosodic levels in the traditional sense. No rule should be able to refer to these levels, and in the case at hand the generalizations are both due to properties of the minimal prosodic word. Syllabification and assignment of lexical tone from suffix are both bounded by the minimal prosodic word.

There is a small but regular pattern of alternation where these, lexically unstressed, pretonic prefixes come out as stressed. The stressed variant occurs postlexically, in complex forms where the prefix modifies a compound (real or formal), cf. Elert (1981, 83). For some reason, the prefix must be promoted to a prosodic word to be able to integrate into a compound (discussion in Riad forthc.).

(22) Primary stress on pretonic prefix

$$
\begin{aligned}
& \left((\text { bé- })_{\omega}(\text { ár })_{\omega}(\text { béta })_{\omega}\right)_{\omega} \max \quad \text { 'work up; belabour' } \\
& \text { ((fö́r- } \left.)_{\omega}(\text { ór })_{\omega}(\text { sáka })_{\omega}\right)_{\omega} \max \text { 'cause' } \\
& \left((\text { fö̀r })_{\omega}(\text { ó })_{\omega}(\text { rắtta })_{\omega}\right)_{\omega} \max \text { 'insult' } \\
& \left((\text { fớr- })_{\omega}(\text { án })_{\omega}(\text { léda })_{\omega}\right)_{\omega} \max \text { 'occasion' }
\end{aligned}
$$

When a pretonic form is integrated as a compound element in its own right, there is no stress alternation: ((be-(tál) $\left.)_{\omega},(\text { kanál })_{\omega}\right)_{\omega} \max$ 'pay channel', ((för-(lóssnings) $\left.)_{\omega}\right)_{\omega}$ ( (sál) $\left.)_{\omega}\right)_{\omega} \max$ 'delivery ward'. The pretonic property is however never challenged, since the prefix remains pretonic, whether it gets stress on itself or not.

\subsection{Prosodically specified morphemes: posttonic}

Posttonic suffixes carry a specification that makes them strive towards being either in the position right after the stressed syllable of a tonic morpheme, or in the position right after a syllable that can receive stress by Rightmost (11), hence a prosodically unspecified morpheme. The posttonic category of morphemes includes pretty much all syllabic suffixes that are not unspecified, including those that vary in syllabicity by epenthesis (e.g. ']-isk,

\footnotetext{
${ }^{17}$ In later work on English, Itô and Mester (2009) argue that a structure very similar to the one given here is true of English words like banana, i.e. $\left(\mathrm{ba}(\text { nana })_{\omega}\right)_{\omega}$, , and call it the extended prosodic word. For Swedish, there is a clear difference between forms like (för(ära) $\left.)_{\omega}\right)_{\omega}$ ' 'bestow' and forms like (veranda) $)_{\omega}$ 'id.', noticeable in syllabification and accent behaviour.
} 
']-en). Inflectional suffixes are also included among the posttonic morphemes, but since they occur outside derivational suffixes, it is often the case that the requirement of posttonicity cannot be met for them (section 4.6). Below, we look first at derivational suffixes.

The posttonic suffixes are of different etymological origin. A number of central types are given according to word class in (23)-(26). For a fuller list, cf. the appendix of Riad (2009b).

(23) Nouns, derivational suffixes

\begin{tabular}{|c|c|c|c|c|c|}
\hline ']-ing & $\begin{array}{l}\text { [snýgg]-ing } \\
\text { [táckl]-ing }\end{array}$ & $\begin{array}{l}\text { 'handsome one' } \\
\text { 'tackle' }\end{array}$ & ]-nad & $\begin{array}{l}\text { [márk]-nad } \\
\text { [prýd]-nad }\end{array}$ & $\begin{array}{l}\text { 'market' } \\
\text { 'decoration' }\end{array}$ \\
\hline \multirow[t]{2}{*}{ ]-ning } & [rä́tt]-ning & 'correction' & & [vắrd]-nad & 'care' \\
\hline & [másk]-ning & 'going slow' & ]-or & [dókt]-or & 'doctor' \\
\hline \multirow[t]{5}{*}{ ']-ling } & [änk]-ling & ‘widower' & & pro[féss]-or & 'id.' \\
\hline & [älsk]-ling & 'darling' & & konser[vát]-or & 'curator' \\
\hline & [sjúk]-ling & 'sickly person' & ']-iker & [mág]-iker & 'magician' \\
\hline & [mýnd]-ling & 'ward' & & alge[brá]-iker & 'algebra expert' \\
\hline & [fém]-ling & 'quintuplet' & ]$-\mathrm{e}^{18}$ & [vék]-e & 'wick' \\
\hline \multirow[t]{3}{*}{ ]-on } & [líng]-on & 'lingonberry' & & [gúbb]-e & 'geezer' \\
\hline & [háll]-on & 'raspberry' & & [Bénk]-e & (Bengt hyp.) \\
\hline & [ód]-on & 'bog bilberry' & ']-a & [sältt]-a & 'salinity' \\
\hline \multirow[t]{4}{*}{ ]-are } & [drág]-are & 'draught animal' & & [hálk]-a & 'slipperiness' \\
\hline & [vín]-are & 'bottle of plonk' & & [năs]-a & 'nose' \\
\hline & [spél]-are & 'player' & & [Kátt]-a & (Katarina hyp.) \\
\hline & bog[sér]-are & 'tower' & & [Lárs]-a & (Lars hyp.) \\
\hline \multirow[t]{4}{*}{ ']-ska } & [brád]-ska & 'haste' & ]-o & [púck]-o & 'stupid one' \\
\hline & [glöm]-ska & 'forgetfulness' & & [míff]-o & 'stupid one' \\
\hline & [jä́mt]-ska & 'woman from Jäm & land' & [hýggl]-o & 'kind person' \\
\hline & stu[dént]-ska & 'female student' & ]-is & [fég]-is & 'coward (hyp.)' \\
\hline \multirow[t]{3}{*}{ ]-else } & [vár]-else & 'being' & & [vákt]-is & 'warden (hyp.)' \\
\hline & [fód]-else & 'birth' & & [föd]-else & 'birth' \\
\hline & [vákt]-is & 'warden (hyp.)’ & & & \\
\hline
\end{tabular}

(24) Adjectives, derivational suffixes

']-ig [grýn]-ig 'grainy', [tál]-ig 'hardy'

\footnotetext{
${ }^{18}$ The endings -e and $-a$ are often considered part of the root, rather than as suffixes (e.g. Kristoffersen 2000 in his treatment of stress). For prosodic purposes (both as regards stress and tone accent) it is more reasonable to treat them as suffixes. For instance, they often go away in compounding (gubb-mage 'old man's belly', nästipp 'tip of the nose').
} 
']-lig [vän]-lig 'friendly', [trév]-lig 'pleasant'

']-(i)sk [kóm]-isk 'comic', [svén]-sk 'Swedish'

']-ad [kórk]-ad 'stupid' kvalifi[cér]-ad 'qualified', [lárm]-ad 'with the alarm set',

']-o [láttj]-o 'fun', [mýsk]-o 'weird', [sól]-o 'lonely', [rék]-o 'alright'

']-is [áv]-is 'envious (hyp.)', [bák]-is 'hung over (hyp.)'

(25) Verbs, derivational suffixes

$\begin{array}{ll}\text { ]-a } & \text { [bók]-a 'book', [tvắtt]-a 'wash', [kálv]-a 'calve' } \\ \text { ']-na } & \text { [vék]-na 'weaken', [smál]-na 'become narrower' }\end{array}$

(26) Participials, derivational suffixes

']-ende [tró]-ende 'believing'

]-ande [tvắtt]-ande 'washing'

']-ad [hämt]-ad 'fetched'

Posttonic suffixes steer stress by Rightmost, to the syllable preceding them, alternatively combine with already stressed syllables, viz. tonic morphemes. Some posttonic suffixes combine with both types. This is in itself an argument for the characterization of the suffixes as precisely posttonic (rather than preaccenting), as it combines these two situations in a natural way. If we characterized this group of suffixes as preaccenting, we would duplicate stress information in both cases (tonic + preaccented, and stressed by RIGHTMOST + preaccented), as tonicity and RIGHTMOST are both independently motivated.

The prosodic specification of suffixes as such is strengthened by the very fact that nearly all syllabic suffixes that are not themselves stressed, are of this kind, whether monosyllabic or disyllabic. Thus, to the extent that the class is describable in terms of morphological generalizations pertaining to prosodic properties, that undermines phonological accounts that fail to capture the morphological ramifications of the posttonic behaviour. Differently put, purely phonological accounts run the risk of employing extrametricality in a way that conceales what is more simply expressed as a morphological generalization over a large class of suffixes.

If there is no tonic morpheme in a structure, or if a tonic morpheme is followed by unspecified morphemes to the right, then the morphemes must be parsed into new prosodic words and stress must be assigned. This amounts to two requirements. First, prosodically unspecified syllables must be parsed, which is the workings of the familiar constraint on EXHAUSTIVITY (Selkirk 1995).

(27) Exhaustivity: No $C^{\mathrm{i}}$ immediately dominates a constituent $\mathrm{C}^{\mathrm{j}}, \mathrm{j}<\mathrm{i}-1$,

'No prosodic word immediately dominates a $\sigma . '$ 
As originally formulated, this requirement also militates against asymmetric parsings across levels. With recursive prosodic domains, it will need to be modified. For our purposes, the central function of this requirement is to see to it that all syllables are incorporated into prosodic words. How this is done will depend on the prosodic specifications of morphemes in a structure, as well as their morphological and semantic status.

The second requirement is the familiar Culminativity, cf. (12). Rightmost will look at the right edge of a form and place a stress there if there is an available syllable. The left edge of the (simplex) word is unimportant. In the examples below, posttonic morphemes are given in combination with tonic morphemes to the left, and in combination with unspecified morphemes to the right.

(28) Posttonic suffixes

\begin{tabular}{|c|c|c|c|c|}
\hline \multirow{3}{*}{ ]-lig } & \multicolumn{2}{|c|}{ following tonic morphemes } & \multicolumn{2}{|c|}{ following unspecified morphemes } \\
\hline & [trév]-lig & 'pleasant' & rekord-ér]-lig & 'reliable' \\
\hline & [ó][ván]-lig & 'unusual' & kontinu-ér]-lig & 'continuous' \\
\hline & [lánd][skáp]-lig & 'landscape-like' & presid-ént]-lig & 'presidential' \\
\hline ]-(i)sk & [grék]-isk & 'Greek' & sisýf]-isk & 'Sisyphus-like' \\
\hline & [dán]-sk & 'Danish' & týp]-isk & 'typical' \\
\hline ]-are & [vín]-are & 'bottle of plonk' & kriminál]-are & 'detective' \\
\hline & brasili[án]-are & 'Brazilian' & marketént]-are & 'canteen manager' \\
\hline & $\mathrm{ka}[$ nót $]$-are & 'canoer' & bogsér]-are & 'tower' \\
\hline & & & sekretér-are & 'secretary' \\
\hline ]-ing & [snýgg]-ing & 'handsome' & diskriminér]-ing & 'discrimination' \\
\hline & [hövd]-ing & 'chieftain' & placér]-ing & 'placement' \\
\hline & för-[säkr]-ing & 'insurance' & rekrytér]-ing & 'recruitment' \\
\hline ]-or & & & proféss]-or & 'id.' \\
\hline & & & mót]-or & 'id.' \\
\hline & & & vékt]-or & 'vector' \\
\hline ]-iker & & & mekán]-iker & 'mechanic' \\
\hline & & & klín]-iker & 'clinician' \\
\hline
\end{tabular}

In forms like kriminál]-are and marketént]-are the stress occurs on syllables that are not lexically specified for stress (i.e. not tonic). This is clear when we compare with other derivational forms like kriminalitét 'crime' and marketenterí '(milit.) canteen' where stress occurs on the last syllable. Similarly, we may compare klín]-iker 'clinician' with klin-ík 'clinic'. In each case, stress occurs in the rightmost available syllable. 
Posttonic specification in derivational endings is robust, such that posttonic suffixes will not permit sequencing, as that would lead to conflicts regarding whose specification should prevail. This is illustrated below with putative, but non-existing forms to the left, and corresponding real forms to the right.

(29) No stacking of derivation posttonic suffixes

$\begin{array}{lll}\text { +păr]-on']-lig } & \text { 'pear-ly' } & \text { cf. păr]-on-ákt]-ig } \\ \text { +býgg]-nads']-lig } & \text { 'building-ly' } & \text { cf. býgg]-nads-mắss]-ig } \\ { }^{+} \text {grý]-ning']-ig } & \text { 'dawn-y' } & \text { cf. grý]-nings-ákt]-ig } \\ { }^{+} \text {sénap']-ig } & \text { 'mustard-y' } & \text { cf. sénaps-ákt]-ig }\end{array}$

The real forms to the right are derived with tonic derivational suffixes (-ákt-, -mä́ss-), and the result is prosodically a compound structure. The absence of stacked posttonic derivational suffixes is predicted by the morphological analysis of stress given here, but goes unexplained in phonological accounts for stress in Swedish. ${ }^{19}$

This static pattern in (29) holds for all posttonic derivational suffixes except one, namely ']-or, as in dókt]-or 'doctor', proféss]-or 'id.'. This suffix allows other posttonic suffixes, and also unspecified suffixes, to follow. Any following suffix will determine the overall stress of the prosodic word that is formed, and this makes it clear that it is ']-or which has this peculiar transparent property. The exceptional behaviour of ']-or is of great interest as it allows us to see clearly that inflectional suffixes, too, are posttonic in character, even though they often fail to exert definitive influence over the placement of stress. In (30), sequences of ']-or followed by other derivational and inflectional posttonic suffixes are given, together with some examples of ']-or followed by an unspecified suffix. Whenever a posttonic subcategorization is not met, this is marked ${ }^{\circ}$, below.

(30) Conflicting suffixes sequenced

\begin{tabular}{|c|c|c|c|c|}
\hline \multirow[t]{3}{*}{ mót]-or } & 'engine' & mot $\left.^{0}\right]$-ór]-isk & 'motoric' & + posttonic \\
\hline & & mot $\left.^{0}\right]$-ór]-er & 'engines' & + posttonic \\
\hline & & $\left.\operatorname{mot}^{0}\right]$-or]-is-ér]-a & 'motorize' & + unspecified \\
\hline \multirow[t]{2}{*}{ dókt]-or } & 'doctor' & dokt $^{0}$ ]-ór]-er & 'doctors' & + posttonic \\
\hline & & dokt $\left.{ }^{0}\right]$-or-ánd & 'Ph.D. student' & + unspecified \\
\hline \multirow[t]{2}{*}{ proféss]-or } & 'professor' & profess $^{0}$ ]-ór]-lig & 'professorial' & + posttonic \\
\hline & & profess $^{0}$ ]-ór]-er & 'professors' & + posttonic \\
\hline pást]-or & 'reverend' & past ${ }^{0}$ ]-or-át & 'parish' & + unspecified \\
\hline
\end{tabular}

\footnotetext{
${ }^{19}$ Tonic derivational suffixes, of course, are fully able to attach in that position: [grább]-ig[-hét] 'laddishness', [frám]-ling[-skáp] 'alienation'.
} 
If ']-lig, ']-ig, ']-isk and plural ']-er were not posttonic, we would expect output forms like *proféssorlig and *proféssorer with stress in the same syllable as in proféssor. That not being the case, we can infer that the placement of stress is determined by the suffixes. Similarly, the unspecified suffixes occurring at the end of the forms doktoránd, pastorát and in the penultimate syllable of motoriséra (']-a being posttonic), show that RIGHTMOST stress is indeed general, and that it applies whenever its structural description is met.

Another case where posttonicity in derivational suffixes is violated is where phonotactic constraints are at stake. In such cases, the suffix ']-lig may occur two syllables away from the stress. Phonotactic constraints are here seen to thwart syncopation of the second syllable (unlike forms where the suffix is vowel initial), (31)a, or where there would be illegitimate attachment of -lig to a preceding [1], (31)b.

(31) Exceptional breach of posttonicity

\begin{tabular}{|c|c|c|}
\hline héder 'honour' & héder ${ }^{0}$-lig 'honest' & *héd•r-lig, cf. héd•r-a 'to honour' \\
\hline sýster 'sister' & sýster $\left.{ }^{0}\right]-$ lig 'sisterly' & *sýst•r-lig, cf. sýst•r-ar 'sisters' \\
\hline sámhälle 'society' & s'amhälle $\left.{ }^{0}\right]$-lig 'societal' & *sámhäll•lig \\
\hline
\end{tabular}

The stability and robustness of posttonicity in suffixes is in itself an argument for the morphological approach to stress assignment in Swedish. A purely phonological account is unable to predict the lack of sequencing of derivational posttonic suffixes. ${ }^{20}$

\subsection{Further generalizations}

We have now seen the core properties of unspecified, tonic, pretonic and posttonic morphemes. Unspecified morphemes trigger RIGHTMOST and exhibit vowel quality and quantity variation in a way that tonic morphemes do not. Pretonic and posttonic affixes occur in their stated positions as shown mostly by static patterns, but each type is also testable against intuition and, in the case of posttonic suffixes, sequencing with the exceptional ']-or. Whenever posttonicity is violated in legitimate output forms, there is a motivating, overriding reason for it, in terms of phonotactics and a few archaic forms which have parallel forms with the expected behaviour. A particular motivating factor in the case of inflectional suffixes is syntax. The requirements of syntax include adding inflections to forms of all kinds. Thus, disyllabic nouns must be able to pluralize, agreement must be

\footnotetext{
${ }^{20}$ This is also one of the reasons we cannot simply supplant 'posttonic' with 'extrametrical'. A posttonic suffix places demands on the preceding syllable, whereas an extrametrical suffix does not. Hence, there should be no hindrance to stacking extrametrical suffixes, or attach them to polysyllabic, initially stressed tonic roots. These behaviours are however limited in the language, indicating that a prosodic specification as posttonic is a better description of these suffixes, than the simple, diacritic invisibility that the notion of extrametricality affords.
} 
expressible on adjectives. In these cases, the posttonic inflections must sometimes bite the bullet and accept being placed away from the stressed syllable.

(32) Posttonic inflections in marked positions

$\begin{array}{ll}\left.\text { církus }{ }^{0}\right] \text {-ar } & \text { 'circuses' } \\ \text { tíd]-ning }] \text {-ar } & \text { 'newspapers } \\ \text { óper }{ }^{0} \text {-or } & \text { 'operas' } \\ \text { tró]-lig }{ }^{0} \text { ]-a } & \text { 'probable, pl.' } \\ \text { héder }]- \text { lig }^{0} \text { ]-are } & \text { 'more honest, comp.' }\end{array}$

We have already seen some indications that (syllabic) inflections are posttonic, notably in combination with ']-or. There are another couple of indications of this. There is the form hútu 'Hutu', which occurs as plural hutú]-er (beside hútuer) with stress shift and also shift of primary stress in the formal compound býrá 'bureau' to the second syllable in the plural, i.e. $\left.b^{0} y r a ́\right]-e r$. An interesting twist to the situation where inflections appear away from the posttonic position in relation to the stress, is to be found in the tonal behaviour. Many inflectional suffixes assign accent 2 whenever the adjacency requirement is met, but this tonal process is inhibited when adjacency fails, and the word will then end up having accent 1. We return to this in section 6.3.

\subsection{Stability}

The morphological view of the stress system and the limited interaction of conflicting specifications provide evidence for the stability of lexical stress. This also harmonizes with some other general facts about Swedish and several other Germanic languages. First, there is the general position of primary stress in older stages of Germanic, which is the root syllable, that is to say the first syllable of the root. It has long been recognized that this position is not primarily phonological (the first syllable), but morphological (the root syllable). This has been true for a very long time, and one might speculate on what this fact should mean for the process of borrowing. When we look at the large-scale borrowings from French (often via German) in the $17^{\text {th }}$ and $18^{\text {th }}$ centuries, it is striking that the original position of stress (as the borrowers would interpret it) in French is retained, almost without exception, that is on the final syllable: gardín 'curtain', balkóng 'balcony', frisýr 'hair-do'. If the Germanic stress system were phonological this would not be quite expected, whereas if stress is morphological, there is nothing in the way for admitting words with stress on some other syllable than the first syllable of the root. To the extent this constitutes an argument it relies on a view of phonologically assigned stress to be more automatic, and thereby harder to control, than morphologically specified stress, other things being equal. 
A related, possible indication of this is the synchronic L2 effects pertaining to stress. There is very little interference of a putative Swedish stress system in the acquisition of foreign languages. Swedes have other difficulties, such as controlling the quantity of stressed syllables (always heavy in Swedish, not so in many other languages), but unlike speakers of Finnish, French or Arabic learning Swedish, there is no pull of stress to the first, last, or last heavy syllable in Swedish learners of foreign languages. This should minimally mean that there is no interference of a phonological stress algorithm on the part of the Swedish learners.

The stability of the Swedish stress system can be attributed in part to culminativity which correlates with minimal prosodic words. If there are two stresses in a form, then that also means that two minimal prosodic words have been created. Conflicting specifications tend not to be generated. Rather than relying on dominance relations in the Greek or Basque sense, the system either generates structures containing more than one minimal prosodic word, or avoids generating prosodically challenging structures in the first place. We shall now take a look at the combinatorics in word formation to see how the prosodic specifications can in fact predict the ostensibly etymological patterns.

\section{Combinatorics}

The prosodic properties of Swedish morphemes make predictions as to what combinations of them should be wellformed or unproblematic, and which combinations should be less felicitous, from the prosodic point of view. Ultimately, this contributes to a characterization of the typical shapes of words in the lexicon as a whole. It would be an exaggeration to say that the prosodic information of morphemes fully determines the form space for morphology. Grammar is dialectic and certain derivations (with-eri, in particular) become productive simply because of their semantic usefulness (cf. SEMANTICNEED in the appendix), in spite of the fact that they sometimes lead to prosodic conflict. In such cases, the prosodic conflict will have to be resolved. Similarly, even though inflectional syllabic suffixes are posttonic (cf. plural ']-er (30) above), syntax drives them to sometimes occur following an unstressed syllable, thus giving rise to a prosodic conflict (cf. SYNTACTICNEED in the appendix). We see various effects of prosodic conflict resolution, which adds important information to our understanding of the shape of the Swedish lexicon, and the word prosody of the language. Paying attention to prosodic specification and combinatory behaviour will thus make predictions regarding what to expect as common and less common patterns, as far as prosody is concerned. Only a cursory presentation can be given here, for a fuller account, cf. Riad (2009b, forthc.). 


\subsection{Harmonic combinations}

There are a number of harmonic combinations of morphemes, listed in (33). In the output forms, minimal prosodic words are marked with ' $\omega$ ' or ' $\omega$ min, projected prosodic words with ' $\omega$ ', and maximal prosodic words with ' $\omega$ max'. Where the maximal projection is the same as the minimal or projected prosodic word, this is not marked.

(33) Harmonic combination morphemes example
a. Tonic + tonic
i. [län $]+[$ stól $]$
result
output structure
gloss
ii. [únder] + [-bár]
two $\omega^{\min } \quad\left((\text { lán })_{\omega}(\text { stól })_{\omega}\right)_{\omega}^{\max }$
'armchair'
two $\omega^{\min } \quad\left((\text { únder })_{\omega}(\text { bár })_{\omega}\right)_{\omega}{ }^{\max }$
'wonderful'
b. Unspec. + tonic
effekt $+[$-fúll $]$
two $\omega^{\min } \quad\left((\text { effékt })_{\omega}(\text { fúll })_{\omega}\right)_{\omega}{ }^{\max }$
'effective'
c. Unspec. + unspec.
i. nat + tion + al + ist
one $\omega^{\min }$
$\left((\text { nat-ion-al-íst })_{\omega}\right)_{\omega}{ }^{\max }$
'id.'
ii. kriminal + assistent
two $\omega^{\min }\left((\text { kriminál })_{\omega}(\text { assistént })_{\omega}\right)_{\omega}{ }^{\max }$
d. Tonic + posttonic [vä́n]+']-lig
'assistant detective'
e. Unspec. + posttonic kriminal+' ]-are
one $\omega^{\min }\left((\text { vắn]-lig })_{\omega}\right)_{\omega}{ }^{\max }$ 'friendly'
f. Pretonic + tonic för-[’ + [ákt]
one $\omega^{\min } \quad\left((\text { kriminál]-are })_{\omega}\right)_{\omega}{ }^{\max }$ 'detective'
one $\omega$ ' $\left(\left(\text { för- }\left([\text { ákt })_{\omega}\right)_{\omega},\right)_{\omega}{ }^{\max }\right.$ 'contempt'

Harmonic combination is the case where no conflict arises between lexical specifications. In (33)a both morphemes are tonic, yielding compounds (i) or derivations with stressed derivational morphemes (ii). Two separate prosodic words are formed. This is also the result in (33)b where the first morpheme is unspecified. It is a general pattern in Swedish word formation that morphemes do not integrate into a minimal prosodic word at the left edge unless there are special conditions requiring it (cf. be- and för- above and below). Sequences of unspecified morphemes as in (33)c integrate into a single prosodic word as long as the morphemes are derivational (i). ${ }^{21}$ The class of neoclassical compounds, which we will not discuss here, form a transitional class as many of them create a single prosodic word (agorafobí 'agora phobia'), while others form two prosodic words (bíomatemátiker 'biomathematician'), and yet others exhibit both outcomes (fótosyntés or fotosyntés 'photo synthesis'). ${ }^{22}$ Thus, a combination of unspecified but semantically sufficiently separate forms is parsed as two prosodic words (kriminálassistént 'assistant detective', ii). Both outcomes are classified as harmonic here, since there is no conflict of specification.

Turning to (33)d,e we have the cases where a posttonic suffix attaches to a tonic or unspecified root. In (33)d there is the perfect match of a lexical stress and the

\footnotetext{
${ }^{21}$ There are no unspecified, inflectional morphemes in Swedish.

${ }^{22}$ The patterning has to do with the lexical status of one or both of the elements included. For instance, if a form commonly occurs in isolation, then it is likely to form its own domain also in compounding.
} 
posttonic requirement of the suffix, and in (33), RiGHTMOST is triggered, where the suffix defines what syllable is the rightmost available one. In (33) we have the combination of pretonic prefix and a tonic root. Pretonic prefixes only ever combine with tonic roots since there are no clear cases of monosyllabic unspecified roots, that do not also require a suffix to form a legitimate output form (e.g. nat-ión 'id.'). Also the combination of pretonic prefix and tonic root, as in förákt 'contempt' is harmonic, but the structure formed is not a fully integrated one, as the prefix is not cosyllabified with the rest. Thus, the structure is (för-(ákt) $\left.)_{\omega}\right)_{\omega}$, syllabified för.ákt rather than *fö.rákt, as would otherwise be expected (cf. ve.rán.da 'id.')

\subsection{Conflicting combinations}

In (34) we have the central conflicting cases.

(34) Conflicting combination

morphemes example result output structure gloss
a. Tonic + unspec.
i. ${ }^{+}[$hemsk $]+-$itet
fails
(sliperí)
'horribil-ity'
ii. [slíp] +-eri
one $\omega^{\min } \quad$ (sliperí) $\omega_{\omega}$
'grindery'
b. Posttonic + posttonic
i. ${ }^{+}$[grý]-ning + ']-ig
fails
'dawn-y'
ii. $\left.\operatorname{mot}^{0}\right]$-ór +$]$-isk) $)_{\omega}$
one $\omega^{\min } \quad$ (motórisk) $\omega$
'motoric'
c. Posttonic + unspec.
i. ${ }^{+}[\operatorname{spél}]-\operatorname{ar}(\mathrm{e})+-$ itet
ii. past $\left.{ }^{0}\right]$-or] + -át) $)_{\omega}$
fails
one $\omega^{\min } \quad$ (pastorát) $\omega$
'player-ism'
fails
'parish'
d. Pretonic + pretonic
+be-[' + för-[kómma]
fails
'make disappear'
e. Pretonic + unspec.
+för-['+ indignéra

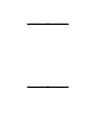
'aggravate'

In general, these are not prosodically felicitous combinations, as is illustrated by the i-cases of (34)abc and by (34)de. The conflicts that still make it into word formation are of two kinds. First, the ii-cases of (34)bc involve the suffix ']-or which is different from the other posttonic suffixes, as discussed above, cf. (30). The exceptionality thus resides in the particular properties of a given suffix, i.e. one that admits following suffixes to override its properties. This behaviour, for morphemes to admit override by other morphemes (either by type or by relative linear position), are typical of domination systems like Greek, Japanese and Northern Bizkaian Basque. The behaviour is, in this sense, regular, as it stems from a lexical property of ']-or. As we have seen, following suffixes of different kinds have the same overriding effect on ']-or. Second, we find the truly exceptional behaviour with (34)a, where semantic properties have made a suffix productive to the extent that it will violate the prosodic conditioning of word formation. We can diagnose the exceptionality in the outcome. Since Culminativity requires exactly one stress per minimal prosodic word, and -eri forms one prosodic word together with what precedes, in this case a tonic root, the 
conflict is a fact. And it is not resolved in a smooth fashion: The quality and some of the length of the lexically stressed syllable is retained even as stress goes to the last syllable by Rightmost, (11). This is a disharmonic resolution, so to speak, but it shows that RightMOST is indeed exceptionless/high-ranking, when its conditions are met.

Beside the productive -eri-formations, there are scattered forms that exhibit similar (prosodically) disharmonic combination, often with a slightly humoristic effect (intended or not). The suffix -tek is a case in point, drawn from borrowings like diskoték 'discotheque', and then added also to tonic roots: lekoték 'play place', filmoték 'film place'. The coinings are used typically for naming some activity room of an institution. Directly humoristic are lustifikatión and muntratión both meaning 'jollification' and to some extent snuttifiéra "divide into snippets, "snippetify". A fair number of forms are created within professional domains, as technical terms, e.g. lastáge '(cargo) loading', läckáge 'leak', seglatión 'sailing', byggnatión 'construction', biljettéra 'issue ticket (for)'. Of the same kind are göticísm 'Geaticism (the idea that the Germanic people originated in Sweden)', prosaíst 'prose writer', danifiéra 'make Danish', stiliséra 'stylize' and versifiéra 'put into verse meter', and also gäldenär 'debtor', borgenär 'creditor'. Yet other forms have become integrated into the general language, e.g. buskáge 'shrubbery', soldát 'soldier', vandaliséra 'vandalize' and lackéra 'to laquer'.

The very fact that several of these forms are slightly comic is in itself a sign of a disharmonic combination. Let us now turn to the etymological perspective.

\subsection{Etymology}

When one takes a cursory look at derivation in Swedish with a view to the etymological properties, one gets the impression that "Germanic" morphemes combine with "Germanic" morphemes, and that "Foreign" morphemes combine with "Foreign" morphemes.

(35) The etymological impression

$\begin{array}{llll}\text { "Germanic" } & (\text { stýr-ning })_{\omega} & \text { 'steering' } & \\ & (\text { fínn-as })_{\omega} & \text { 'exist' } & \\ & (\text { lýs-ande })_{\omega} & \text { 'brilliant' } & { }^{+} \text {lys-ant } \\ \text { "Foreign" } & (\text { naviga-tión })_{\omega} & \text { 'navigation' } & \\ & (\text { exist-éra })_{\omega} & \text { 'exist' } & \\ & (\text { brilj-ánt })_{\omega} & \text { 'brilliant' } & { }^{+} \text {brilj-ande }\end{array}$

We would not want to try to explain this synchronic pattern, by reference to etymology, as that would be to appeal to the diachrony of the morphemes. If one insists on an etymological view, then that will be synchronically turned into a learned pattern, which will predict that children will have to reconstruct a divided lexicon that correponds to the etymological 
divide. This should not be an impossibility in principle (cf. the view of Japanese lexicon as organized into parts), but it would leave a number of issues to explain, such as the conditions under which the etymological boundaries are crossed over.

We will attempt instead to explain the seeming etymological divide in terms of overt, prosodic specification. The combinatorics under the model developed here in fact predicts where the crossovers should be natural and frequent, and where they would be infelicitous in the prosodic perspective. Thus, our view is that certain classes are filled with predominantly unspecified morphemes ("foreign"), and others by predominantly tonic, posttonic and pretonic morphemes ("Germanic"). However, there are morphemes that have been recategorized in both directions. The interesting argument is to be made in the area of combinatorics.

The cases discussed at the end of section 5.2 above were crossover formations that are exceptional in relation to the general pattern, i.e. prosodically disharmonic combinations that have survived. The large class here is all the disharmonic combinations that do not make it into the language. Equally, we would predict that where there is no conflict, word formation should thrive. The best category here is the combination of unspecified morpheme + posttonic suffix. The former are overwhelmingly foreign in origin, while the latter are mostly Germanic in origin. But there is also a group of foreign suffixes that are posttonic (e.g. ']-iker). The suffix ']-are is originally Latinate, but this can only be guessed with linguistic knowledge in hand. Here are a number of combinations of this kind, all of which are natural to intuition and lacking humoristic qualities.

(36) Foreign unspecified root + Germanic posttonic suffix

$\begin{array}{llll}\text { rekordér-lig } & \text { 'good, reliable' } & \text { speciál-are } & \text { '(a) special' } \\ \text { persón-lig } & \text { 'personal' } & \text { gardér-ing } & \text { 'hedging' } \\ \text { kontinuér-lig } & \text { 'continuous' } & \text { summér-ing } & \text { 'summation' } \\ \text { natúr-lig } & \text { 'natural' } & \text { rubricér-ing } & \text { 'heading' } \\ \text { symmétr-isk } & \text { 'symmetric' } & \text { klassificér-ing } & \text { 'classification' } \\ \text { periód-isk } & \text { 'periodic' } & \text { miljonăr-ska } & \text { 'female millionaire' } \\ \text { episód-isk } & \text { 'episodic' } & \text { frisör-ska } & \text { 'female hair dresser' } \\ \text { analóg-isk } & \text { 'analogical' } & \text { studént-ska } & \text { 'female student' }\end{array}$

The etymological approach would also find problems with the harmonic combination of unspecified roots (of foreign origin) with tonic Germanic suffixes. This is however a fully productive and natural combination, as predicted by the prosodic approach advocated here. The first stress in each form in (37) is assigned by RiGHTMOST. 
(37) Foreign unspecified root + Germanic tonic suffix

$\begin{array}{llll}\text { kontrollér-bár } & \text { 'controllable' } & \text { redaktör-skáp } & \text { 'editorship' } \\ \text { datér-bár } & \text { 'datable' } & \text { revísor-skáp } & \text { 'auditorship' } \\ \text { effékt-fúll } & \text { 'striking' } & \text { kontúr-lös } & \text { 'vague' } \\ \text { respékt-fúll } & \text { 'respectful' } & \text { respékt-lös } & \text { 'disrespectful' } \\ \text { temperaménts-full } & \text { 'temperamental' } & & \end{array}$

These patterns tell us that etymology (sometimes crudely instantiated as [ \pm native] and the like) will not be enough to explain preferences and avoidances in word formation, anyway. With a morphological stress system like the one proposed, the relevant etymological information comes down as prosodic specification, no more complex than what we find in other languages with prosodic dominance relations among morphemes.

The general predictions regarding crossover that the morphological model makes would thus seem to be met. Conflict has an inhibiting effect on word formation of certain types, or else appears intuitively marked and slightly comic. In the case of productivity developing in spite of the prosodic conflict (-eri), a dominance relation is revealed (here RightMOst determines stress over a lexical specification). Harmonic combination, on the other hand, exhibits frequent crossover between etymological classes and is also intuitively natural. The controlling factor is CULMINATIVITY, at the level of the minimal prosodic word.

\section{Tone accent in Swedish}

\subsection{Culminativity of the maximal prosodic word}

At the level of the maximal prosodic word, Culminativity holds, but is not strictly obligatory. As indicated in (2), it is instantiated by tone accent. To see this, one must separate the prominence function of any tone accent realized in intonation, from the distinction made among tone accents (accents 1 and 2), at each level of prominence. These things are charted in (38), where the typical uses of the two prominence levels are indicated to the right.

(38) Tone accents and prominence levels

\begin{tabular}{|l|l|l|l|l|}
\hline & accent 1 & accent 2 & $\begin{array}{l}\text { accent } 2 \text { in } \\
\text { compounds }\end{array}$ & typical functions \\
\hline $\begin{array}{l}\text { Prominence } \\
\text { level 2 }\end{array}$ & $\mathrm{L}^{*} \mathrm{H}$ & $\mathrm{H}^{*} \mathrm{LH}$ & $\mathrm{H}^{*} \mathrm{~L}^{*} \mathrm{H}$ & $\begin{array}{l}\text { initiality, focus, topic, } \\
\text { contrastive topic }\end{array}$ \\
\hline $\begin{array}{l}\text { Prominence } \\
\text { level } 1\end{array}$ & $\mathrm{HL}^{*}$ & $\mathrm{H}^{*} \mathrm{~L}$ & $\mathrm{H}^{*} \mathrm{~L}$ & $\begin{array}{l}\text { given material, second } \\
\text { occurrence focus, new }\end{array}$ \\
\hline
\end{tabular}




\begin{tabular}{|l|l|l|l|}
\hline & & & $\begin{array}{l}\text { material (when non-final } \\
\text { in the phrase) }\end{array}$ \\
\hline
\end{tabular}

To understand how culminativity is instantiated in Swedish it is in fact not necessary to heed neither the tonal distinction, nor the difference between the two prominence levels. All tone contours indicated in (38) instantiate culminativity. Which one of the two accents is realized is due to lexical information in the case of simplex form, and to a postlexical rule in the case of compounds (and other structure containing two stresses). The level of prominence is determined by the usual factors that influence intonation in Germanic languages, i.e. focus, contrast, givenness, etc., though for prominence level 1 it really looks like each maximal prosodic word gets an accent by default, suggesting that accent at this level motivated at the prosodic word level. In addition to this there is a boundary marking function for initiality (Myrberg 2010; cf. also Roll et al. 2009). The tonal contours of prominence level 2 are used in the initiality marking function.

The non-obligatoriness of culminativity at the level of the maximal prosodic word means that lexical words should sometimes be unaccented in running speech. We have mentioned some of these cases (section 2), e.g. verbs in construction with an object or adverbial (spela kúla 'play with marbles', komma hém 'come home'). ${ }^{23}$

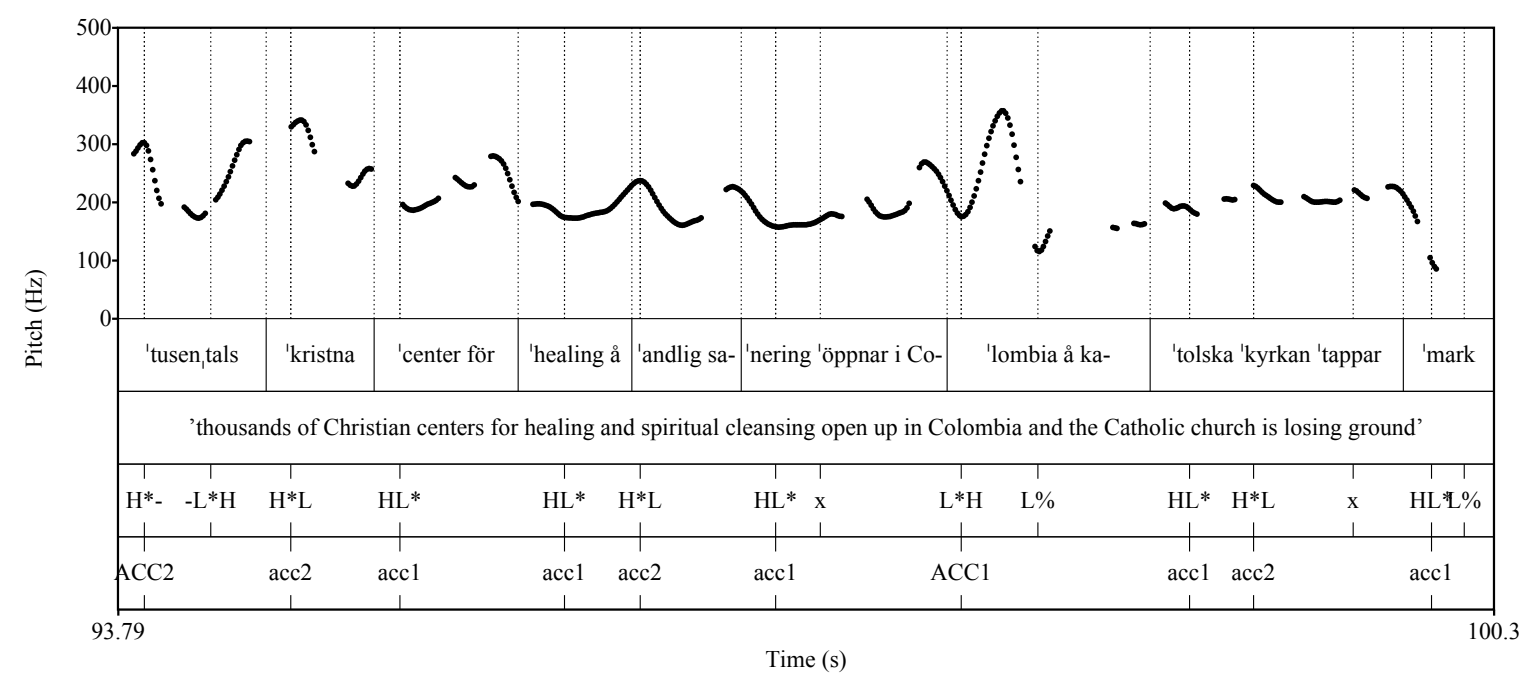

Figure 1. Prominence level 2 is illustrated in a compound (tusentals 'thousand') and simplex Colombia ('ACC' in the bottom tier). Other accents are at prominence 1 ('acc' in the bottom tier). Some stressed syllables are not accented (marked ' $x$ ' in the tonal tier): öppnar 'open', táppar 'loses'. From Människor och tro ('People and faith', Swedish Radio, P1). Reproduced with permission.

\footnotetext{
${ }^{23}$ In running speech, forms that do not receive an accent may show up inside intonational plateaus which stretch from one accented syllable to another (Myrberg 2010, 82).
} 
As seen in Figure 1, many words are accented, hence expressing culminativity in the maximal prosodic word. The two prominence levels are indicated with uppercase 'ACC' for the higher prominence level 2, and lowercase 'acc' for prominence level 1. The digit following this mark indicates the lexical contrast, i.e. whether it is accent 1 or accent 2 in a given word.

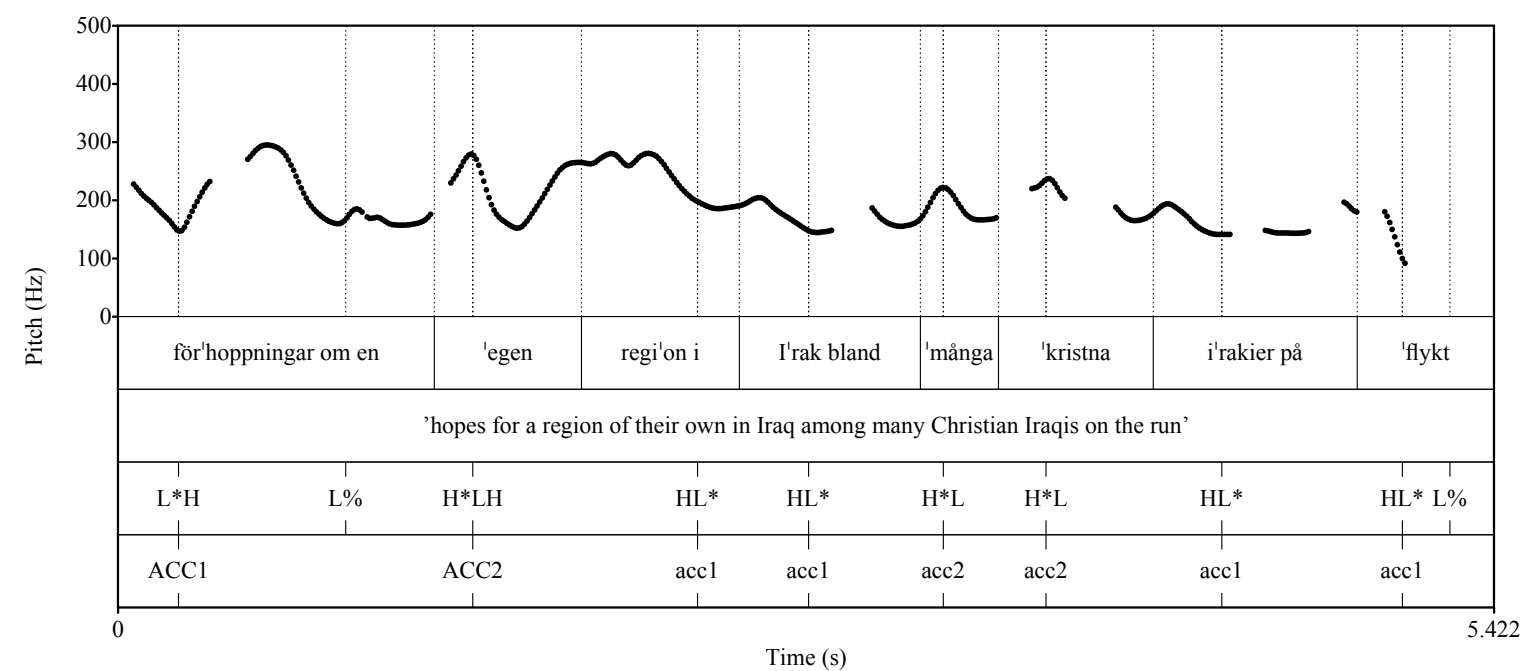

Figure 2. Accent 1 and accent 2 at both prominence levels. The bottom tier indicates prominence level. In the tonal tier, the associated tone (marked ' $*$ ') is coordinated with the tonal contour. The two first accents are prominence level 2, all the following are prominence level 1. From Människor och tro ('People and faith', Swedish Radio, P1). Reproduced with permission.

Compounds can appear in either prominence level, but are seldom unaccented. Figure 3 is an example of prominence level 1 in two, long compounds.

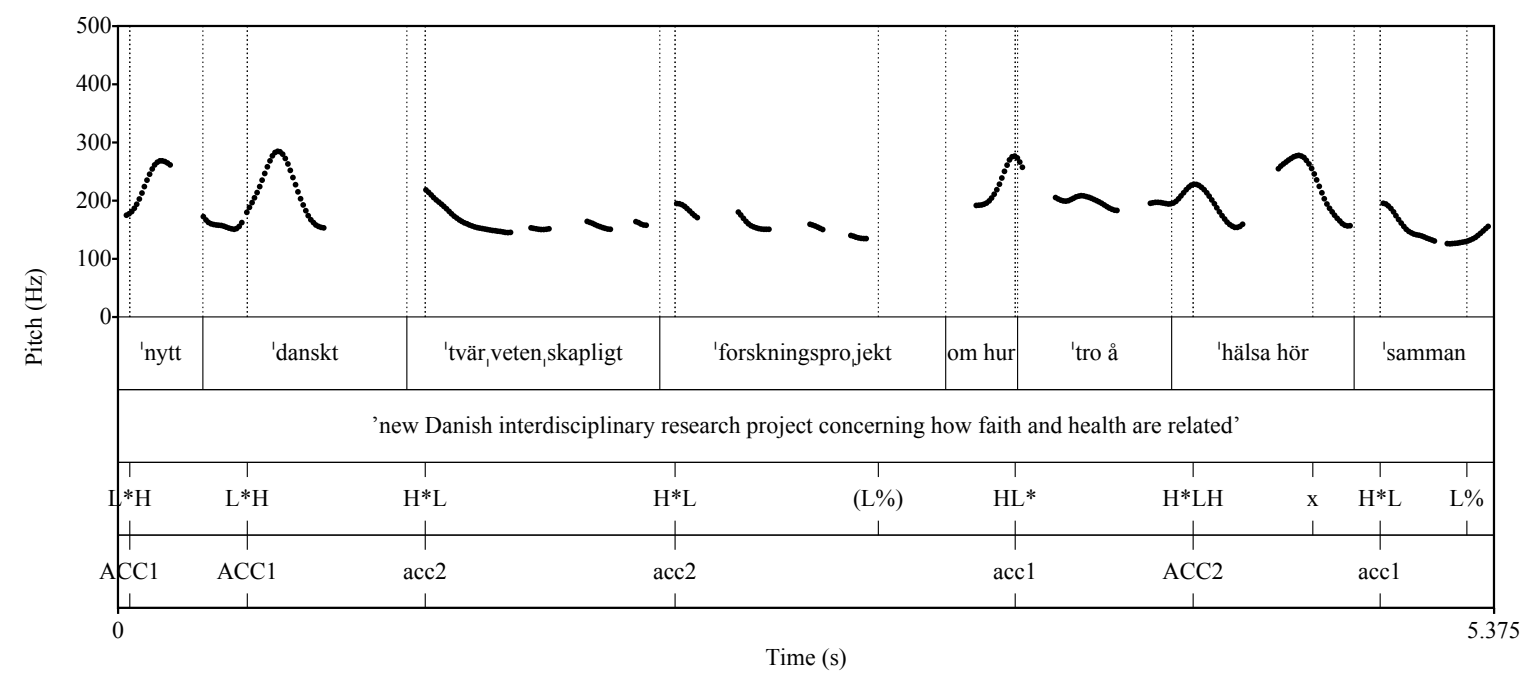

Figure 3. Prominence level 1 in compounds: tvärvétenskápligt 'interdisciplinary' and fórskningsprojékt 'research project'. From Människor och tro ('People and faith', Swedish Radio, P1). Reproduced with permission. 
There is only one accent in each prosodic word. Note in particular that in compounds, which are constituted by several minimal prosodic words, there can only ever be a single accent. Beside the prominence level 1 examples in Figure 3, there is a prominence level 2 compound in the beginning of Figure 1, túsentáls 'thousands'.

\subsection{Assignment of tone accent}

The assignment of tone accent is partly lexical, partly intonational. ${ }^{24}$ Consider first the lexical distinction, which in Central Swedish amounts to a lexical $\mathrm{H}$ tone in accent 2 and no lexical tone in accent $1 .{ }^{25}$

(39) Representation of tone in morphemes

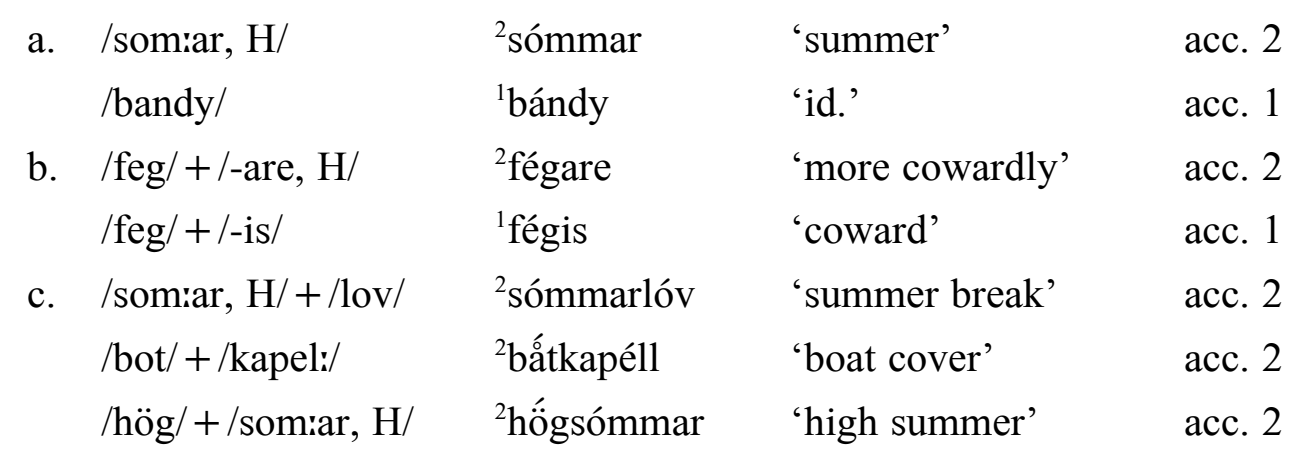

The cases in (39)a illustrate the contrast between roots, where ${ }^{2}$ sómmar is lexically marked for a lexical $\mathrm{H}$ tone, and ${ }^{1}$ bándy is not. Accent 2 is thus the marked member of a privative

\footnotetext{
${ }^{24}$ There are several analyses of North Germanic accent around, where the issue of lexical status of tone in simplex forms is one of the main points on which analytical approaches differ: Lexical accent 2 - Rischel (1963), Haugen (1967), Bruce (1977), Riad (1998b, 2009b), Kristoffersen (2000); Lexical accent 1 - Lahiri et al. (2005), Wetterlin (2007, 2010), Kristoffersen (2006); No lexical accent - Morén (2007). These differences of approach reflect theoretical differences, as well as a lack of consensus on what the basic facts are. It is therefore no trivial task to sort out the predictions, or to evaluate the relative success of the different approaches. A very useful attempt at just that, however, is given in the recent dissertation of Naydenov (2011).

For the chief proposal regarding tone accent in this article - word accent expresses culminativity at the level of the maximal prosodic word - it does not really matter how accent is accounted for, as long as the domain of the maximal prosodic word is recognized (under some name), and tonal prominence is regularly assigned or contained in it. The actual contrast is not important for that generalization to hold, cf. (38) and discussion there. The view that lexical accent is often assigned from suffixes, and under locality (cf. (40)), is important in the wider perspective of a diachronic relationship between stress and tone accent (Riad 1998a), and the stable contexts across dialects (Riad 1998b). It is no coincidence, we argue, that the set of posttonic suffixes is coextensive with the set of accent-2 inducing suffixes. Indeed, posttonicity and locality refer to the same context.

${ }^{25} \mathrm{I}$ assume here that accent 2 is lexically just the $\mathrm{H}$ tone, rather than the fall HL. Arguments for this can be drawn from prominence level 2 in compounds, where the association pattern of HLH clearly splits the contour into $\mathrm{H}^{*}$ (on the first stressed syllable/TBU) and $\mathrm{L}^{*} \mathrm{H}$ (on the last stressed syllable/TBU), cf. (44) below.
} 
opposition, accent 1 being reducible to pure intonation. Lexical accent 2 in roots is fairly limited and also subject to variation between dialects (Bruce 1998, 50). The vast majority of accent 2 forms in any text is constituted by suffix-induced accent 2 . The contrast is illustrated in (39)b. Most posttonic syllabic suffixes carry a lexical tone with them, and the set of suffixes is the same in dialect after dialect. Examples of derivational suffixes are $-i g_{2}, \quad-\mathrm{lig}_{2}, \quad-i n g_{2}, \quad-\mathrm{nad}_{2}, \quad-\mathrm{are}_{2 \mathrm{No \textrm {M }}}, \quad-\mathrm{else}_{2}, \quad-\mathrm{or}_{2 \mathrm{No \textrm {M }}}$, etc., and of inflectional suffixes $-a r_{2},-a e_{2 \text { сомр }},-o r_{2 \mathrm{pL}},-e l_{2}$, etc. There are very few syllabic, posttonic suffixes that do not also induce accent 2 (the two most prominent are both hypocoristic: - $i s_{0}$, feg-is 'coward', and $-o_{0}$, puck-o 'stupid one'). In (39)c we have compounds, or more precisely, structures that contain two stresses, and they invariably get accent 2 , but via a postlexical compound rule that is sensitive to the presence of more than one stress in a maximal prosodic word.

The tonal information in suffixes is however expressed only under favourable conditions, and this is how we learn about the lexical nature of accent, and its residence in suffixes. We shall look at two such patterns, locality and strength of accent induction.

\subsection{Locality}

The first favourable case for accent assignment is locality. When the posttonic requirement on stress location of the suffix is not met, as is quite frequently the case with inflectional suffixes, accent 2 assignment from the suffix is inhibited. There are two cases, indicated in (40)bc below. Lexical accent is marked with ' 2 ' at the end of the suffix. Tonally unspecified suffixes are marked 'ø' for clarity. The accent of the whole form is marked with a raised '2, or "' before the primary stressed syllable. Like before, a raised ' 0 ' marks instances where the posttonic suffix is not in the posttonic position, hence when locality is not met.

(40) Posttonic inflectional accent 2-suffixes in local and non-local position.

\begin{tabular}{|c|c|c|c|c|}
\hline \multirow[t]{4}{*}{ a. sg. } & ${ }^{1}$ bíl & 'car' & pl. ${ }^{2}$ bíll]-ar $_{2}$ & acc. 2 \\
\hline & ${ }^{1}$ rós & 'rose' & ${ }^{2}$ rós]-or 2 & acc. 2 \\
\hline & ${ }^{1}$ gód & 'good' & ${ }^{2}$ gód]- $\mathrm{a}_{2}$ & acc. 2 \\
\hline & ${ }^{2}$ kánn]-a ${ }_{2}$ & 'jug’ & ${ }^{2}$ kánn]-or 2 & acc. 2 \\
\hline b. sg. & ${ }^{2}$ dríbbl]-ing 2 & 'dribble' & pl. ${ }^{2}$ dríbbl]-ing $\left.{ }_{2}^{0}\right]-\operatorname{ar}_{2}$ & acc. 2 \\
\hline & ${ }^{2}$ trév]-lig 2 & 'nice' & ${ }^{2}$ trév]-ligg $\left.{ }_{2}^{0}\right]-\mathrm{a}_{2}$ & acc. 2 \\
\hline & ${ }^{2}$ sót]-ig 2 & ‘sooty’ & ${ }^{2}$ sót $\left.]-\mathrm{ig}_{2}{ }^{0}\right]-\mathrm{e}_{2}$ & acc. 2 \\
\hline \multirow[t]{5}{*}{ c. } & 'církus & 'circus' & pl. ${ }^{1}$ církus $\left.{ }^{0}\right]-\mathrm{ar}_{2}$ & acc. 1 \\
\hline & ${ }^{1}$ klématis & 'clematis' & ${ }^{1}$ klématis $\left.{ }^{0}\right]-\mathrm{ar}_{2}$ & acc. 1 \\
\hline & ${ }^{1}$ kómp]-is & 'friend' & $\left.{ }^{1} \mathrm{komp}-\mathrm{is}_{0}{ }^{0}\right]-\mathrm{ar}_{2}$ & acc. 1 \\
\hline & ${ }^{1}$ óper $\left.^{0}\right]-\mathrm{a}_{2}$ & 'id.' & ${ }^{1}$ óper $\left.{ }^{0}\right]-$ or $_{2}$ & acc. 1 \\
\hline & ${ }^{1}$ kámer] $-\mathrm{a}_{2}$ & 'camera' & ${ }^{1}$ kámer $\left.^{0}\right]-$ or $_{2}$ & acc. 1 \\
\hline
\end{tabular}


The cases in (40)a illustrate the canonical case, where accent is assigned from the suffix. When the suffix is away from the stressed syllable, two patterns are in evidence. If the preceding syllable is a derivational posttonic suffix which itself induces accent 2 , the whole structure will get accent 2, as in (40)b. This should be attributed to the derivational suffix, which is in the posttonic position. If there is no accent 2 information in the structure preceding the inflectional suffix, however, accent 2 will not be assigned, as in (40)c. We take this to be evidence of the fact that the suffix is canonically posttonic, such that it fails to assign its accent 2 when away from that canonical position. Another way of putting this is to say that suffixes are preaccenting regarding tone, since they actually assign their tone to a preceding stressed syllable. This amounts to two accentual specifications in the suffixes: posttonic for stress, and preaccenting for tone. Posttonicity must be met for preaccentuation to take place.

\subsection{Strength of accent induction}

The other case where accent assignment is challenged is when the stressed syllable is not initial in the form. This is called anacrusis. For some reason, anacrusis has an inhibiting effect on the assignment of accent, but it turns out that suffixes differ in how well they resist anacrusis (Riad 2009a). Two groups are clearly discernable and we will simply call them strong and weak accent 2-inducing suffixes. Contrasting forms that provide evidence for a difference between suffixes in this regard are given in (41), where (a), different suffixes attach to the same root, and (b), similar or homophonic suffixes attach to different roots. The tonal outcome differs. In canonical forms, i.e. when stress is initial, all of these suffixes induce accent 2, e.g. ' ${ }^{2}$ trás]-ig 'broken' and ${ }^{2}$ trév]- lig $_{2}$ 'nice', as we have seen above.

(41) Strong and weak accent-2-inducing suffixes

\begin{tabular}{|c|c|c|c|c|}
\hline \multirow{3}{*}{ a. } & \multirow{3}{*}{$\begin{array}{l}\text { Strong } \\
\text { profes }^{2} \text { sór]-ska }\end{array}$} & \multicolumn{3}{|c|}{ Weak } \\
\hline & & 'wife of professor' & profes $^{1}{ }^{\text {sór] }}-\mathrm{er}_{2}$ & 'professors' \\
\hline & & & profes $^{1}$ sór]- $^{-\operatorname{lig}_{2}}$ & 'professorial' \\
\hline & bog $^{2}$ sér]-are ${ }_{2}$ & 'tower' & bog $^{1}$ sér]- $a_{2}$ & 'to tow' \\
\hline & & & bog $^{1}$ sér]-ing 2 & 'act of towing' \\
\hline b. & mo²rás]-ig & 'morassy' & per'són]-lig $_{2}$ & 'personal' \\
\hline & dis $^{2}$ trä] $-\operatorname{ing}_{2}$ & 'distracted one' & sor $^{1}$ tér]-ing 2 & 'sorting' \\
\hline & speciª́ll]-are $_{2 \mathrm{NOM}}$ & 'a special' & speci $^{1}$ éll]-are ${ }_{2 \text { сомР }}$ & 'more special' \\
\hline
\end{tabular}

This pattern shows that accent varies systematically with suffix, under systematic prosodic conditions. While in canonical contexts, they all induce accent 2 , in anacrusis context, they fall neatly into two groups, however without any obvious motivation for exactly where the split occurs (some discussion is given in Riad 2009b). Any analysis of Swedish tone accent 
that does not take these suffix-bound morphological generalizations regarding the distribution of tone accent into account, will also fail to express them. ${ }^{26}$

\subsection{Culminativity by postlexical rule}

From the point of view of culminativity, the most interesting feature is postlexical accent assignment, that is, prominence given by intonation, without the interference of the lexical tone of accent 2. In lexically toneless forms (i.e. accent 1) there is no lexical tonal information to heed, only a stressed syllable, the TBU of all tonal association in Swedish. As shown in (38), the tonal configuration of prominence level 1 is HL. This accent occurs on almost every lexical word, except the cases of deaccentuation. It is easier to define the loci where accent is not assigned than to define the instances where accent is assigned (Myrberg 2010). This amounts to a hypothesis that all maximal prosodic words are assigned accent by default. The prominence level 1 accent is HL, but different association patterns yield different timings for the two accents. That is how the distinction is maintained in running speech (Bruce 1977). The timing difference is quite visible in Figure 2, above. For accent 1, the association is $\mathrm{HL}^{*}$, which we may take as the default. For accent 2, the association is $\mathrm{H}^{*} \mathrm{~L}$, which we take to follow from the accomodation of the lexical tone, which is $\mathrm{H}^{*}$, and which is invariably associated, when realized. I will assume that the lower prominence level HL accent is simply merged with the lexical $\mathrm{H}^{*}$ in accent 2 , yielding $\mathrm{H}^{*} \mathrm{~L}$.

(42) Prominence level 1

$\begin{array}{llll} & \mathrm{H}^{*} & \mathrm{HL}^{*} & \mathrm{H}^{*} \mathrm{~L} \\ \text { kétchup } & \text { sénap } & \text { kétchup } & \text { sénap } \\ \text { 'ketchup' } & \text { 'mustard' } & & \text { accent1 }\end{array}$

In prominence level 2, accentuation is caused by the insertion of a prominence LH tone, in both word accents. The association of this tone will depend on the availability of a TBU. In accent 1 , primary stress is free to associate a tone, hence $\mathrm{L}^{*} \mathrm{H}$. In accent 2 , primary stress is taken by lexical $\mathrm{H}^{*}$, and the $\mathrm{LH}$ tone of prominence level 2 will float right after the lexical tone, in simplex words.

(43) Prominence level 2

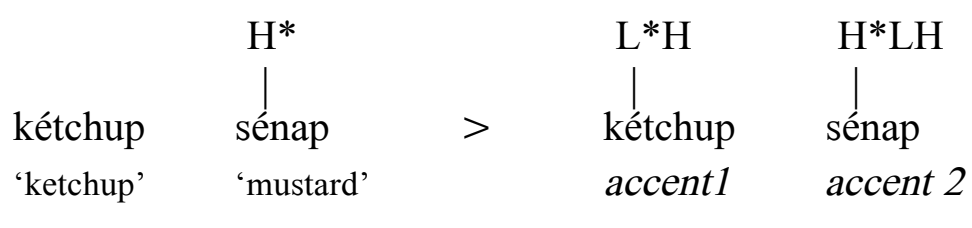

\footnotetext{
${ }^{26}$ Further indications pointing in the direction of lexical representation of tone accent 2 in suffixes has recently come through in the ERP study by Roll et al. (2010).
} 
In accent 1 , the relevant tonal contour is simply added in each of the prominence levels. For accent 2 , there is merger in prominence level 1 and sequencing in prominence level 2. This means that association of the initial $\mathrm{L}$ of $\mathrm{L}^{*} \mathrm{H}$ will not be able to take place whenever the stressed syllable is already "taken" by a lexical H tone, which always has priority. Thus, LH comes to float after the lexical tone (cf. Bruce 1987). In compounds, however, there are always more than one minimal prosodic word, hence always more than one stressed syllable available. This allows for two tones to be associated, as discussed directly below.

\subsection{Culminativity and compounds}

The culminativity effect of the maximal prosodic word is manifest by the limitation to one tone accent per word. In a compound, however long, there will always only ever be just one tone accent, and that is accent 2 with a particular association pattern. In Central Swedish, this accent is always assigned by the phonology, cf. (39)c. The compound rule of Central Swedish will associate a $\mathrm{H}^{*}$ to the first stressed syllable. This is the "same" tone as lexical accent 2 . If the compound occurs in prominence level 1, then the HL contour is assigned, coalescing with $\mathrm{H}^{*}$. If the compound occurs in prominence level 2 , the $\mathrm{L}^{*} \mathrm{H}$ will be assigned. Since there are more stresses present in the structure (unlike the case in simplex forms), there will be at least one free TBU for the $\mathrm{L}^{*} \mathrm{H}$ to associate to. The resulting pattern is that $\mathrm{L}^{*} \mathrm{H}$ invariably associates to the last stress in the maximal prosodic word. Any lexical tonal information belonging to individual morphemes in the compound is invisible at the stage where compound accent is assigned. Like before, such morphemes are marked ', , to the left in (44).

(44) Compounds: prominence levels 1 and 2

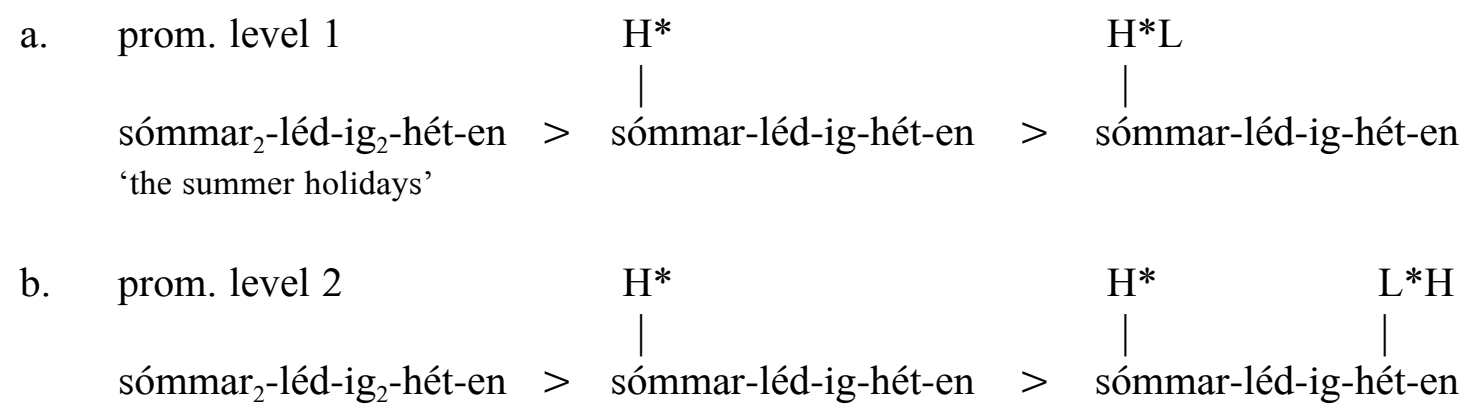

In prominence level 2, the $\mathrm{L}$ tone of $\mathrm{L}^{*} \mathrm{H}$ of spreads backwards to the first stressed syllable instantiating a fall there, and a rise in the last stressed syllable. The contrast between prominence levels in compounds is illustrated in Figure 1 (tusentals 'thousands', prominence level 2) and Figure 3 (tvärvétenskápligt 'interdisciplinary', fórskningsprojékt 'research project', prominence level 1). 
Culminativity, then, is instantiated in different ways at the different levels of prominence, and it depends on what tonal information is present or absent in the form, but it is implemented with near-obligatoriness, and certainly more often than in English. Possibly, the regularity with which accent is assigned is part of the often perceived "singsong" quality of Central Swedish speech.

Many other languages have similar, (fully or partly) postlexical rules for culminativity in larger structures, notably compounds. Greek exhibits at least three different types of formation (Nespor and Ralli 1993).

(45) Greek compound formation

a. Stem + stem $>$ penultimate or antepenultimate

$\begin{array}{lll}\text { spírto 'match' + kutí 'box' } & >\text { (spirtokúti) })_{\omega} & \text { 'match box' } \\ \text { kúkla 'doll' + spíti 'house' } & >\text { (kuklóspito) })_{\omega} & \text { 'doll's house' }\end{array}$

b. Stem + word $>$ accent of second member (word)

$$
\begin{array}{lll}
\text { péfko 'pine' + ðásos 'forest' } & >\text { (pefkoðásos })_{\omega} & \text { 'pine forest' } \\
\text { xartí 'paper' }+ \text { petséta 'napkin' }>(\text { xartopetséta })_{\omega} & \text { 'paper napkin' }
\end{array}
$$

c. Word + word $>$ both accents retained, phrase formed

$$
\begin{array}{lll}
\text { zóni 'security' + asfalías 'belt' } & >\left((\text { zóni })_{\omega}(\text { asfalías })_{\omega}\right)_{\Phi} & \text { 'security belt' } \\
\text { nómos 'law' }+ \text { plésio 'frame' } & >\left((\text { nómos })_{\omega}(\text { plésio })_{\omega}\right)_{\Phi} \text { 'law frame (lit.)' }
\end{array}
$$

Culminativity within the prosodic word is instantiated in (45)ab where one or both of the members are stems.

Osaka Japanese (Haraguchi 1977, 96) has rule mixing lexical and postlexical information, whereby the left-hand member of a compound determines the accent of the whole compound, by placing that accent in the right-hand member.

(46) Osaka Japanese compounding

a. ya ${ }^{\mathrm{HL}} \mathrm{ma}+$ sakura $>$ yama-za ${ }^{\mathrm{HL}} \mathrm{kura}$

'mountain' ${ }^{\mathrm{L}} \mathrm{a}^{\mathrm{HL}}+$ scherry'
sakura

'morning' 'cherry'

b. tuki ${ }^{\mathrm{HL}} \mathrm{mi}+$ dan $^{\mathrm{L}} \mathrm{go}^{\mathrm{H}}>$ tukimi-da $^{\mathrm{HL}}$ ngo

'appreciation of the moon' 'dumpling' 
There are several other compound formations in varieties of Japanese (cf. Itô and Mester 2007), some of which are prosodic words, others phrases.

In Northern Bizkaian Basque, culminativity in compounds is expressed as one accent per prosodic word. Out of two unaccented compound members, accent goes to the last syllable of the first element. If the first element is accented, then that accent stays.

(47) Northern Bizkaian Basque (Getxo) compounding

a. unaccented + unaccented: place accent on the last syllable of the first element

$\begin{array}{llll}\text { buru }+ \text { andi } & > & \text { burú-andi } & \text { 'big-headed' } \\ \text { sagu }+ \text { sarr-a } & > & \text { sagú-sarra } & \text { 'bat (lit. old mouse)' } \\ \text { elis }+ \text { ate } & > & \text { elís-ate } & \text { 'church door' }\end{array}$

b. accented + unaccented: retain the accent of the initial element, cf. (9) bélarr + ondo $>$ bélarr-ondo 'side of face'

There are further patterns in this language, but this is the most regular and productive (Hualde and Bilbao 1992, 41, Hualde 2003).

The Swedish compound pattern described here is that of the variety of Central Swedish. Similarly conditioned patterns occur in other dialects of Swedish and Norwegian, e.g. Dala, Göta and North Norwegian. In other dialects, notably South Swedish, accent may be predominantly determined by properties in the first compound member, such as a lexical tone there (Bruce 1973, Riad 1998b). We saw this in Northern Bizkaian Basque compounding, and similar cases have been reported for Kagoshima Japanese (Uwano 2007, Kubozono 2007) and other Japanese varieties (Haraguchi 1977). Other factors, e.g. the prosodic shape of the left edge of the whole compound (anacrusis or initial stress), and the distance between stresses in the middle of the compound, as well as morphological grouping may also influence the resultant accent in South Swedish.

\section{Conclusion}

The exposition of Swedish stress above brings Swedish closer to the dominance systems of Japanese, Basque and Greek, in that morphemes are taken to be prosodically specified in different ways that determine and/or influence the resultant stress pattern. The big difference resides in the very limited override of prosodic specifications in Swedish word formation. Where typical dominance systems have regular override in cases of conflicting specification, Swedish instead avoids generating those structures, or forms more complex structures within the prosodic word, i.e. by admitting several minimal prosodic words, each their own culminativity domain, into one maximal prosodic word. This latter strategy, one might speculate, is admissible in part because of the tonal instantiation of culminativity that holds 
in the larger structure, i.e. the postlexical compound rule. A number of advantages appear to follow from abandoning the overly phonological approaches to stress, that have been current in the analysis of stress in Germanic languages. Certainly for Swedish, a number of generalizations within the realm of word formation are captured, as well as some strong limitations on the sequencing of morphemes.

\section{Appendix: notes on the grammar}

In this appendix, a sketch of a formal account of the stress system is given. This will serve as a summary of the observations made for Swedish, and an indication of how factors involved in the stress system of Swedish interact. The constraint rankings are indicated in a charts given at the end.

The basic specifications of prosodic information relating to stress create a baseline for the derivational morphology. Roots and derivational morphemes subject to faithfulness are tonic (roots, suffixes, prefixes), posttonic (suffixes) or pretonic (prefixes). Given specifications are protected by faithfulness constraints. Violation is minimal and occurs only under the pressure of overriding concerns (Prince and Smolensky 1993). We may call this factor RoOt/DerivationalFaith (RT/DERFAITH). The analysis given above builds on the basic idea that prosody indeed has great influence over the derivational morphology of Swedish, such that harmonic combination of prosodic properties come at no cost, while disharmonic combination should come at a cost, here cast as the violation of RT/DERFAITH. Such a grammar predicts that harmonic combination should be common, and that there should be a reason for disharmonic combination when that occurs. With posttonic suffixes the patterns are overwhelmingly harmonic (trév]-lig 'nice', cf. (28)), with the two pretonic prefixes, fully harmonic (för-[déla 'distribute', cf. (21)). However, we identified regular override with the suffix -eri, and this means that there is a semantic pressure, summarized here as SEMANTICNEED (to cover both the productive cases, and the more lonely cases we have seen, cf. seglatión, section 5.2). SEMANTICNEED (SEMNEED) is higher ranking than RTDERFAITH and may hence drive forth derivation with morphemes that have conflicting prosodic specifications, even when that means that a lexical stress has to be removed, as was the case with sliperí 'grindery', (34)), or that a posttonic specification has to be ignored, the case with känd]-is-erí 'interest in famous people' (a much less common case).

The stress behaviour here indicates that the constraint of CULMINATIVITYPRWD (CULM) must be undominated: a minimal prosodic word contains one stress only, so when there is a struggle, one solution is for the leftmost stress to delete. This in turn exhibits the fact that stress has to be as far to the right in the word, as possible. This was expressed by Rightmost, which must also be high-ranking. In any structure containing a prosodically 
unspecified suffix at the end, stress will go to the final syllable (kalif, pro-duk-tiv-itét 'productivity', slip-erî). If the suffix is posttonic, stress will go to the syllable right before that suffix (banalisér]-a 'banalize'). The factor that triggers RIGHTMOST stress assignment in forms that already have a stress in them, is EXHAUSTIVITY, cf. (27).

Turning to the inflectional morphemes, these morphemes largely carry the same type of lexical specifications as derivational suffixes, i.e. they are posttonic when syllabic. However, their grammatical status is different. In particular, they are dominated by syntactic constraints in a way that derivational suffixes are not. This is, of course, a common divide, exploited in many models of morphology. For our purposes, it means that whenever syntactic constraints require e.g. agreement in number, let us call this SyNTACTICNEED (SYNTNEED), the inflectional suffixes must implement that agreement, and hence attach, whether or not it involves a violation of posttonicity, call it INFLECTIONALFAITH (INFLFAITH). Thus, harmonic bíl]-ar 'cars' and disharmonic káktus $\left.{ }^{0}\right]$-ar 'cactuses' must both be generated by the grammar.

There is one more factor relating to stress that we must specify here, and that is the peculiar behaviour of the derivational suffix -or, which unlike all the other derivational suffixes, is transparent and allows other derivational suffixes to attach outside of it. This is exceptional behaviour in the present analysis (not so in Morén 2007, however), and we also register it as exceptional: -OR-FAITH. This constraint must be ranked below all other faithfulness constraints pertaining to the realization of stress. In particular, it ranks below inflectional suffixes: mot ]-ór]-er 'engines' (cf. jón]-er 'ions'), not *mót]-or ${ }^{0}$ ]-er (cf. káktus ] ${ }^{0}-a r$ 'cactuses', gry]-ning ]-ar 'dawns').

These are all the major forces involved in the stress system that we have discussed in this article. Below is an overview of the ranking and workings of it. Crucial interactions are marked with ' $\checkmark$ ' vs '*'. A single mark of either kind draws attention to the relevance of a given constraint for a particular form. Tonic morphemes are underscored, for clarity. Morphological structure is indicated with hyphens.

Table 1. Stress interactions

\begin{tabular}{|c|c|c|c|c|c|c|c|c|c|}
\hline & & $\begin{array}{c}\text { SEM } \\
\text { NEED }\end{array}$ & $\begin{array}{l}\text { SYNT } \\
\text { NEED }\end{array}$ & CULM & $\begin{array}{c}\text { EXHAUS- } \\
\text { TIVITY }\end{array}$ & $\begin{array}{l}\text { RIGHT } \\
\text { MOST }\end{array}$ & $\begin{array}{c}\text { RT/DER } \\
\text { FAITH }\end{array}$ & $\begin{array}{c}\text { INFL } \\
\text { FAITH }\end{array}$ & $\begin{array}{c}\text { OR- } \\
\text { FAITH }\end{array}$ \\
\hline a. & pyjámas & & & & & & $\checkmark$ & & \\
\hline a.' & *pyjamás & & & & & & $* !$ & & \\
\hline b. & trév]-lig & & & & & & & & \\
\hline c. & trév]-lig $\left.{ }^{0}\right]-\operatorname{are}_{\text {сомР }}$ & & & & & & $\checkmark$ & * (']-are) & \\
\hline d. & kalíf & & & & & $\checkmark$ & & & \\
\hline e. & elektr-ic-itét & & & & & $\checkmark$ & & & \\
\hline f. & banal-is-ér]-a & & & & & $\checkmark$ & $\checkmark$ & & \\
\hline f.' & *banal-is-er]-á & & & & & $\checkmark$ & $* !$ & & \\
\hline g. & slip-erí & $\checkmark$ & & $\checkmark$ & & $\checkmark$ & * (slip) & & \\
\hline
\end{tabular}




\begin{tabular}{|c|c|c|c|c|c|c|c|c|c|}
\hline g.' & *slíp-eri & $\checkmark$ & & $\checkmark$ & $* !(-$ eri) & $\checkmark$ & $\checkmark$ & & \\
\hline g." & *slíp-erí & $\checkmark$ & & $* !$ & & $\checkmark$ & $\checkmark$ & & \\
\hline h. & känd]-is-erí & $\checkmark$ & & & $\checkmark$ & & ** $\underset{\text { ]-is })}{\text { känd, }}$ & & \\
\hline i. & bíl]-ar & & $\checkmark$ & & & & $\checkmark$ & $\checkmark$ & \\
\hline j. & káktus $\left.{ }^{0}\right]$-ar & & $\checkmark$ & & & & $\checkmark$ & $*$ & \\
\hline $\mathrm{k}$. & grý]-ning $\left.{ }^{0}\right]$-ar & & $\checkmark$ & & & & $\checkmark$ & $*$ & \\
\hline k.' & *gry]-níng]-ar & & $\checkmark$ & & & & $\begin{array}{l}* * \text { (gry, } \\
\text { ]-ning) }\end{array}$ & $\checkmark$ & \\
\hline 1. & mót]-or & & & & & & & & $\checkmark$ \\
\hline $\mathrm{m}$. & mot $^{0}$ ]-ór]-er & & & & & & & $\checkmark$ & $*$ \\
\hline m.' & ${ }^{*}$ mót]-or ${ }^{0}$ ]-er & & & & & & & $* !$ & $\checkmark$ \\
\hline & & $\begin{array}{c}\text { SEM } \\
\text { NEED } \\
\end{array}$ & $\begin{array}{l}\text { SYNT } \\
\text { NEED } \\
\end{array}$ & CULM & $\begin{array}{c}\text { EXHAUS- } \\
\text { TIVITY }\end{array}$ & $\begin{array}{l}\text { RIGHT } \\
\text { MOST }\end{array}$ & $\begin{array}{c}\text { RT/DER } \\
\text { FAITH }\end{array}$ & $\begin{array}{c}\text { INFL } \\
\text { FAITH }\end{array}$ & $\begin{array}{c}-O R- \\
\text { FAITH } \\
\end{array}$ \\
\hline
\end{tabular}

The upshot here is that we are likely to learn the most about prosodic specification in Swedish by looking at word formation, where prosodic properties appear to play a constitutive role. Since inflection is under the thumb of syntax, so to speak, it will not reveal as much about the stress system. However, inflection tells us a few things about the tonal system, such as the import of locality. The tonal system appears to be reactive in Swedish, revealing its canonical properties under favourable conditions, and often hiding them, when conditions are unfavourable.

\section{Acknowledgements}

I would like to acknowledge here two generous grants that have supported the research reported in this paper: The first is from the Bank of Sweden Tercentenary foundation (), and the other from the Knut and Alice Wallenberg foundation, mediated by the Swedish Academy. Thanks are due to Josefin Bloch and Sara Myrberg for discussion of the general approach to stress and accent given here. Haruo Kubozono and José Ignacio Hualde, as well as two anonymous reviewers, have given me much valuable input that has significantly improved the paper. All errors are mine.

\section{References}

Alderete, J., 2001. Dominance effects as transderivational anti-faithfulness. Phonology 18, 201-253.

Andréasson, A.-M., 1997. Swedish word accents. Doctoral dissertation. University of Illinois, Urbana-Champaign. [publ. 2001, Lincom Europa, München]

Anward, J., Linell, P., 1976. Om lexikaliserade fraser i svenskan. Om lexikaliserade fraser i svenskan. Nysvenska studier 55-56, 77-119. 
Baeskow, H., 2004. Lexical properties of selected non-native morphemes of English. Gunter Narr, Tübingen.

Bailey, L. M., 1990. A Feature-based Analysis of Swedish Pitch Accent and Intonation.

Doctoral dissertation, University of Delaware, Newark, DE.

Basbøll, H., 2005. The Phonology of Danish. (The Phonology of the world's languages)

Oxford University Press, Oxford.

Beckman, M., 1986. Stress and non-stress accent. Foris, Dordrecht.

Blevins, J., 1993. A tonal analysis of Lithuanian nominal accent. Language 69.2, 237-273.

Bruce, G., 1973. Tonal accent rules for compound stressed words in the Malmö dialect.

Working papers 7, 1-35. Phonetics laboratory, Lund University.

Bruce, G., 1977. Swedish word accents in sentence perspective. (Travaux de l'institut de linguistique de Lund 12) CWK Gleerup, Lund.

Bruce, G., 1987. How floating is focal accent? In: Gregersen, K., Basbøll, H. (Eds.). Nordic

Prosody IV. Odense University Press, Odense. pp. 41-49.

Bruce, G., 1998. Allmän och svensk prosodi. (Praktisk Lingvistik 16.) Lund University.

Elert, C.-C., 1981. Ljud och ord i svenskan 2. Almqvist and Wiksell International, Uppsala.

Elordieta, G., 1997. Accent, tone, and intonation in Lekeitio Basque. In: Martínez-Gil, F.,

Morales-Front, A. (Eds.), Issues in the Phonology and Morphology of the Major Iberian

Languages. Georgetown University Press, Washington, D.C. pp. 3-78

Elordieta, G., 2003. Intonation. In: Hualde, J. I., Ortiz de Urbina, J. (Eds.), A Grammar of

Basque. Mouton de Gruyter, Berlin. pp. 72-113

Elordieta, G., 2007. A constraint-based analysis of the intonational realization of focus in

Northern Bizkaian Basque. In: Riad, T., Gussenhoven, C. (Eds.), Tones and Tunes:

Volume I, Typological Studies in Word and Sentence Prosody (Phonology and

Phonetics 12-1). Mouton de Gruyter, Berlin. pp. 199-232.

Féry, C., 1996. German foot and word stress in OT. Nordlyd 24, 63-96.

Frid, J. 2003. Lexical and Acoustic Modelling of Swedish Prosody (Travaux de l'institut de linguistique de Lund 45), Lund University Press, Lund.

Gussenhoven, C., 1999. Tone systems in Dutch Limburgian dialects, In: Kaji, S.

(Ed.), Proceedings of the Symposium on Cross-Linguistic Studies of Tonal Phenomena:

Tonogenesis, Typology, and Related Topics. Institute for Languages and Cultures of

Asia and Africa, Tokyo University of Foreign Languages, Tokyo. pp. 127-143.

Gussenhoven, C., 2004. The Phonology of Tone and Intonation, Cambridge University

Press, Cambridge.

Hammond, M., 1999. The phonology of English. An prosodic optimality-theoretic approach.

Oxford University Press, Oxford.

Haugen, E., 1967. On the rules of Norwegian tonality. Language 43, 185-202. 
Haraguchi, S., 1977. The tone pattern of Japanese: an autosegmental theory of tonology. Kaitakusha, Tokyo.

Hualde, J. I., 1999. Basque accentuation. In van der Hulst, H. (ed.), Word Prosodic Systems in the Languages of Europe, 947-993. Berlin: Mouton de Gruyter.

Hualde, J. I., 2003. Some ways in which Basque is and is not like Japanese. Proceedings of the Symposium Cross-Linguistic Studies of Tonal Phenomena

Hualde, J. I., Bilbao, X., 1992. A phonological study of the Basque dialect of Getxo. Gipuzkoako Foru Aldundia, Donostia, San Sebastian.

Hualde, J. I., Lujanbio, O., Torreira, F., 2008. Lexical tone and stress in Goizueta Basque. Journal of the International Phonetic Association 38.1, 1-24.

Hualde, J. I., Lujanbio, O., Zubiri, J. J., 2010. Goizueta Basque. Journal of the International Phonetic Association 40.1, 113-127.

Hyman, L. M., 2006. Word-prosodic typology. Phonology. 23, 225-257.

Hyman, L. M., 2009. How (not) to do phonological typology: The case of pitch-accent. Language Sciences 31, 213-238.

Hyman, L. M., 2011. Tone: Is it Different?. In: Goldsmith, J., Riggle, J., Yu, A. (Eds.), The Handbook of Phonological Theory, $2^{\text {nd }}$ edition, Wiley-Blackwell. pp. 197-239.

Inkelas, S., Zec, D., 1988. Serbo-Croatian pitch accent: The interaction of tone, stress, and intonation. Language 64.2, 227-248.

Itô, J., Mester, A., 2006. Prosodic Adjunction in Japanese Compounds. Proceedings of FAJL 4, Osaka, 2006.

Itô, J., Mester, A., 2007. Categories and Projections in Prosodic Structure. Presentation OCP 4, Rhodes.

Itô, J., Mester, A., 2009. The extended prosodic word. In: Kabak, B., Grijzenhout, J., (Eds.), Phonological Domains: Universals and Derivations. Mouton de Gruyter, The Hague, pp. 135-194.

Jessen, M., 1999. German. In: van der Hulst, H. (Ed.), Word Prosodic Systems in the Languages of Europe. Mouton de Gruyter, Berlin. pp. 515-545.

Jun, S.-A., Elordieta, G., 1997. Intonational structure of Leketio Basque. In: Botinis, A., Kouroupetroglou, G., Carayiannis, G. (Eds.), Intonation: Theory, Models and Applications, Athens, Greece. pp. 193-196.

Kager, R., 1989. A metrical theory of stress and destressing in English and Dutch. Foris, Dordrecht.

Karinšs, A. K., 1996. The prosodic structure of Latvian. Doctoral dissertation. University of Pennsylvania, Philadelphia, PA.

Kooij, J., 2003. Blocking participial ge- in Dutch: prosody or syntax? ms. University of Leiden. 
Kristoffersen, G., 2000. The Phonology of Norwegian. (The Phonology of the world's languages) Oxford University Press, Oxford.

Kristoffersen, G., 2006. Markedness in Urban East Norwegian tonal accent. Nordic Journal of Linguistics 29.1, 95-135.

Kubozono, H., 2007. Tonal change in language contact: Evidence from Kagoshima Japanese. In: Riad, T., Gussenhoven, C. (Eds.), Tones and Tunes: Volume I, Typological Studies in Word and Sentence Prosody. Mouton de Gruyter, Berlin. pp. 323-351.

Lahiri, A., Wetterlin, A., Jönsson-Steiner, E., 2005. Lexical specification of tone in North Germanic. Nordic Journal of Linguistics 28, 1, 61-96.

Linell, P., Anward, J., 1971. Synpunkter på betoningens roll i svenskans prosodi. ms. Uppsala universitet, Uppsala.

Linell, P., 1972. Remarks on Swedish morphology. RUUL 1, Uppsala universitet, Uppsala. Morén, B., 2007. Central Swedish Pitch Accent: a retro approach. Presentation OCP 4, Rhodes.

Myrberg, S., 2010. The intonational phonology of Stockholm Swedish (Stockholm studies in Scandinavian philology 53). Stockholm.

Naydenov, V., 2011. Issues in the phonology of the tonal accents in Swedish and their Norwegian and Danish counterparts. Doctoral dissertation, University of Sofia.

Nespor, M. Ralli, A., 1993. Stress domains in Greek compounds: A case of morphology/phonology interaction. In: Philippaki-Warburton, I., Nicolaidis, K., Sifianou, M. (Eds.), Themes in Greek linguistics. (CILT 117) John Benjamins, Amsterdam.

Öhman, S., 1967. Word and Sentence Intonation: A quantitative model. Speech Transmission Laboratory Quarterly Progress and Status Report (STL-QPSR) 2-3, 20-54. Dept. of Speech Transmission, Royal Institute of Technology, Stockholm.

Peters, J., 2007. A bitonal lexical pitch accent in the Limburgian dialect of Borgloon. In: Riad, T., Gussenhoven, C. (Eds.), Tones and Tunes: Volume I, Typological Studies in Word and Sentence Prosody (Phonology and Phonetics 12-1). Mouton de Gruyter, Berlin. pp. 167-198.

Prince, A., Smolensky, P., 1993. Optimality theory: Constraint interaction in generative grammar. Ms, Rutgers University and University of Colorado, Boulder.

Revithiadou, A., 2007. Colored Turbid accents and Containment: A case study from lexical stress. In: Blaho, S., Bye, P., Krämer, M. (Eds.), Freedom of Analysis? Mouton de Gruyter, Berlin. pp. 149-174.

Riad, T., 1998a. The origin of Scandinavian tone accents. Diachronica XV:1, 63-98. 
Riad, T., 1998b. Towards a Scandinavian accent typology. In: Kehrein, W., Wiese, R.

(Eds.), Phonology and Morphology of the Germanic Languages. (Linguistische Arbeiten 386) Niemeyer, Tübingen. pp. 77-109.

Riad, T., 1999. Allting ryms i varje frö. Om suffixet -(i)sk. Språk och stil 9, 35-70.

Riad, T., 2002. Svensk smeknamnsfonologi. Studia Anthroponymica Scandinavica 20, 5198.

Riad, T., 2009a. The morphological status of accent 2 in North Germanic simplex forms. In: Vainio, M., Aulanko, R., Aaltonen, O. (Eds.), Nordic Prosody. Proceedings of the Xth Conference, Helsinki 2008. Peter Lang. pp. 205-216.

Riad, T., 2009b. Prosodi i svenskans morfologi. ms Department of Scandinavian languages, Stockholm University, Stockholm.

Riad, T., forthc. The Phonology of Swedish. (The Phonology of the world's languages) Oxford University Press, Oxford.

Rischel, J., 1963. Morphemic tone and word tone in Eastern Norwegian. Phonetica 10, 154164.

Rice, C., 2006. Norwegian stress and quantity: The implications of loanwords. Lingua 116, 1171-1194.

Roll, M., Horne, M., Lindgren, M., 2009. Left-edge boundary tone and main clause verb effects on syntactic processing in embedded clauses - An ERP study. Journal of neurolinguistics 22, 55-73.

Roll, M., Horne, M., Lindgren, M., 2010. Word accents and morphology-ERPs of Swedish word processing. Brain research 1330, 114-123.

Schmid, B., 1987. Non-linear approaches to Swedish word prosody. Doctoral dissertation, Brown University, Providence, RI.

Selkirk, E., 1995. The prosodic structure of function words. In: Beckman, J., Walsh Dickey, L., Urbanczyk, S. (Eds.), Papers in Optimality Theory. Amherst, Mass.: GLSA. 439470. [Republished as: The prosodic structure of function words. 1996. In Morgan, J. L., Demuth, K. (Eds.), Signal to syntax. Bootstrapping from speech to grammar in early acquisition. Lawrence Erlbaum Associates, Mahwah, NJ. pp. 187-213.]

Shokri, N., 2001. An OT account of Swedish lexical word stress. Proceedings of the 18th Scandinavian Conference of Linguistics. pp. 103-111.

Teleman, U., 1969. Böjningssuffixens form i svenskan. Arkiv för nordisk filologi 84, 163208.

Trommelen, M., Zonneveld, W., 1999. Word-stress in West-Germanic: English and Dutch. In: van der Hulst (Ed.), Word Prosodic Systems in the Languages of Europe, Mouton de Gruyter, Berlin. pp. 477-514.

Uwano, Z., 2007. Two pattern accent systems in three Japanese dialects. In: Riad, T., Gussenhoven, C. (Eds.), Tones and Tunes: Volume I, Typological Studies in Word and 
Sentence Prosody (Phonology and Phonetics 12-1). Mouton de Gruyter, Berlin. pp. 147166.

Weinstock, J. M., 1970. A Sketch of Norwegian phonology. In: Benediktsson, H. (Ed.), The Nordic languages and modern linguistics. (Vísindafélag Islendinga 39) Reykjavík. pp. 572-598.

Wetterlin, A., 2007. The Lexical specification of Norwegian tonal word accents. Doctoral dissertation, University of Konstanz.

Wetterlin, A., 2010. Tonal accents in Norwegian: phonology, morphology and lexical specification. De Gruyter, Berlin.

Wiese, R., 1996. The Phonology of German. (The Phonology of the world's languages) Oxford University Press, Oxford. 